\title{
Liver X Receptors and their Agonists: Targeting for Cholesterol Homeostasis and Cardiovascular Diseases
}

\author{
Zhiqiang $\mathrm{Ma}^{1,2,3, \#, \text { Chao Deng,"\#, Wei Hu}}{ }^{2, \#, ~ J i e ~}$ \\ Zhou ${ }^{5}$, Chongxi Fan ${ }^{3}$, Shouyin $\mathrm{Di}^{3}$, Dong Liu', \\ Yang Yang ${ }^{1,2, *}$, and Dongjin Wang ${ }^{1, *}$ \\ ${ }^{1}$ Department of Thoracic and Cardiovascular \\ Surgery, Affiliated Drum Tower Hospital of \\ Nanjing University Medical School, 321 \\ Zhongshan Road, Nanjing 210008, Jiangsu, \\ China \\ ${ }^{2}$ Department of Biomedical Engineering, The \\ Fourth Military Medical University, 169 Changle \\ West Road, Xi'an 710032, China \\ 32Department of Thoracic Surgery, Tangdu \\ Hospital, The Fourth Military Medical University, \\ 1 Xinsi Road, Xi'an 710038, China \\ ${ }^{4}$ Department of Cardiovascular Surgery, Xijing \\ Hospital, The Fourth Military Medical University, \\ 127 Changle West Road, Xi'an 710032, China \\ ${ }^{5}$ Department of Medical Engineering, Beidaihe \\ Sanatorium, Beijing Military Area Command, 4 \\ West Beach Road, Qinhuangdao 066100, China \\ ${ }^{6}$ State Key Laboratory of Cardiovascular \\ Disease, Fuwai Hospital, National Center for \\ Cardiovascular Diseases, Chinese Academy of \\ Medical Sciences and Peking Union Medical \\ College, 167 Beilishi Road, Beijing 100037, \\ China
}

\#These authors contributed equally to this work. *Correspondence: dongjinwang210@163.com (Dongjin Wang) and yang200214yy@163.com (Yang Yang)

DOI: http://dx.doi.org/10.21775/cimb.022.041

\footnotetext{
Abstract

Liver $X$ receptors $\alpha(L X R \alpha)$ and $\beta(L X R \beta)$ are essential for protection against cardiovascular diseases. LXRs are members of the nuclear receptor superfamily of DNA-binding transcription factors and act as sensors of cholesterol homeostasis. In this review, we introduce LXRs and briefly describe the roles of LXRs in reverse cholesterol transport and trans-intestinal
}

cholesterol efflux. We discuss LXR agonists and the downstream genes of LXRs that are involved in the regulation of cholesterol transport. In addition, we describe the cardioprotective effects of LXRs against atherosclerosis, myocardial ischemia/reperfusion injury, diabetic cardiomyopathy, and myocardial hypertrophy. Finally, we expand our discussion to the actions of LXRs in atherosclerosis and suggest several potential research avenues that may be of interest to clinicians and basic scientists. The information included herein may be useful for the design of future experimental research studies and may advance the investigation of LXRs as therapeutic targets.

\section{Introduction}

Liver $X$ receptors (LXRs) are members of the nuclear receptor superfamily of DNA-binding transcription factors and are sensors of cholesterol homeostasis. The LXR subfamily contains two isoforms, $\alpha$ and $\beta$ (Ulven et al., 2005), which are regulated by the binding of physiological ligands (e.g., oxysterols and desmosterol) (Peet et al., 1998a; Yang et al., 2006), and synthetic LXR agonists (e.g., GW3965 and T0901317) (Harasiuk et al., 2015; Kappus et al., 2014). Cardiovascular diseases are the most common causes of mortality and morbidity worldwide, and emerging evidence shows that LXRs play cardioprotective roles in maintaining cholesterol homeostasis (Hong and Tontonoz, 2014), suppressing inflammation (Kappus et al., 2014), decreasing oxidation and apoptosis (He et al., 2014a), and suppressing insulin resistance (He et al., 2014b) and hypertrophy (Kuipers et al., 2010a).

The focus of this review is to summarize the latest progress regarding the protective effects of LXRs in cholesterol homeostasis and cardiovascular diseases. First, we briefly discuss the background information of LXRs and their roles in cholesterol transport. Then, we provide 
in-depth descriptions of the downstream genes of LXRs in the regulation of cholesterol transport and LXR agonists that are involved in antiatherogenic activities. Next, we summarize the cardioprotective roles of LXRs against myocardial ischemia/reperfusion injury, diabetic cardiomyopathy, and myocardial hypertrophy. Finally, we discuss several novel potential directions for future research on LXRs. The presented information is potentially useful for the design of future studies and the advancement of LXRs as therapeutic targets for cardiovascular diseases.

\section{General background on LXRs and their roles in cholesterol transport \\ LXRs}

LXRs are members of the nuclear receptor superfamily of DNA-binding transcription factors. In humans, LXR $\alpha$ and LXR $\beta$ are located on the short arm of chromosome 11 (11p11.2) and the long arm of chromosome 19 (19q13.3), respectively. Human LXRa (447 amino acids) and LXRß (460 amino acids) share $77 \%$ sequence homology in both their full-length DNA and their ligand-binding domains (Pannu et al., 2013; Zhao and Dahlman-Wright, 2010). LXRs contain four principal domains, including an Nterminal ligand-independent activation function domain, a DNA-binding domain, a ligand-binding domain that is required for ligand binding and receptor dimerization, and a C-terminal liganddependent activation function-2 domain, which stimulates transcription in response to ligand binding and is requisite for binding co-activators or co-repressors (Faulds et al., 2010).

The transcriptional activity of LXRs is dependent on heterodimerization with retinoid $X$ receptors (RXRs) (Peet et al., 1998b). LXR-RXR heterodimers bind to the LXR response element (LXRE), a specific DNA sequence represented by repeated AGGTCA sequences that are separated by four nucleotides (DR4 response elements) (Apfel et al., 1994; Peet et al., 1998b). A genome-wide analysis has confirmed that DR4 response elements are present in the regulatory regions of many targets and that they play a role in determining LXR binding to DNA (Quack et al., 2002). When not bound to a ligand, the LXRRXR heterodimer remains bound to the promoter region of target genes in a complex with corepressors, such as silencing mediator of retinoic acid and thyroid hormone receptor (SMRT) or nuclear receptor co-repressor (NCoR) (Hu et al.,
2003), to inhibit the activation of target genes (Svensson et al., 2003). Once bound to an agonist, the conformation of the LXR-RXR complex is altered, leading to the release of the $\mathrm{NCoRs}$ and the recruitment of nuclear receptor co-activators, such as activating signal cointegrator 2 (ASC2) (Kim et al., 2009) and E1Aassociated protein p300 (EP300) (Huuskonen et al., 2004) (Figure 1A). Although both LXR a and LXR $\beta$ are activated by the same ligands and are structurally similar, their tissue expression profiles are very different. LXR $\alpha$ is selectively expressed in specific tissues and cell types, such as the liver, intestine, adrenal gland, adipose tissue and macrophages, whereas LXR $\beta$ is ubiquitously expressed (Huuskonen et al., 2004; Peet et al., 1998a; Peet et al., 1998b).

\section{LXRs and reverse cholesterol transport}

Cholesterol removal from non-hepatic cells and its delivery back to the liver for excretion are processes collectively known as reverse cholesterol transport (RCT) (Francis, 2010). Elevated flux through the RCT pathway is thought to protect against cardiovascular diseases primarily by facilitating the removal of cholesterol from macrophage foam cells in atherosclerotic plaques (Rosenson et al., 2012). Several direct LXR target genes are closely associated with the RCT pathway, including genes encoding membrane lipid transporters, such as ATP-binding cassette subfamily $A$ type 1 (ABCA1), ABCG1, ABCG5 and ABCG8; apolipoproteins (Apos), such as ApoE; and lipid transfer proteins and cholesterol metabolizing enzymes, such as cholesterol 7-a-hydroxylase (CYP7A1) (Pannu et al., 2013).

At the cellular level, $A B C A 1$ and $A B C G 1$ transport cellular cholesterol to ApoA1 and highdensity lipoprotein (HDL), respectively. Then, the lipidated lipoprotein particles transport cholesterol back to the liver via low-density lipoprotein receptor (LDLR) and HDL receptor scavenger receptor class B type 1 (SR-B1), which perform selective lipid uptake from HDL into hepatocytes. Finally, the cholesterol is secreted into bile or catabolized into bile acids via a process that is modulated by CYP7A1 (Hong and Tontonoz, 2014). In $\mathrm{Lxr}^{\prime-}$ mice, cholesterol removal from the body is severely impaired (Joseph et al., 2003). In contrast, the systemic activation of LXRs in mice by synthetic LXR agonists reduces plasma cholesterol levels and raises plasma HDL levels (Joseph et al., 
2002; Tangirala et al., 2002; Wang and Tall, 2003) (Figure 1B).

\section{LXRs and trans-intestinal cholesterol excretion} Biliary cholesterol secretion is the primary mechanism for excess cholesterol excretion from the body. However, cholesterol excretion can also be facilitated by a non-biliary pathway known as trans-intestinal cholesterol efflux (TICE) (Khera and Rader, 2010). TICE involves the movement of cholesterol through the plasma to the basolateral surface of enterocytes. Then,

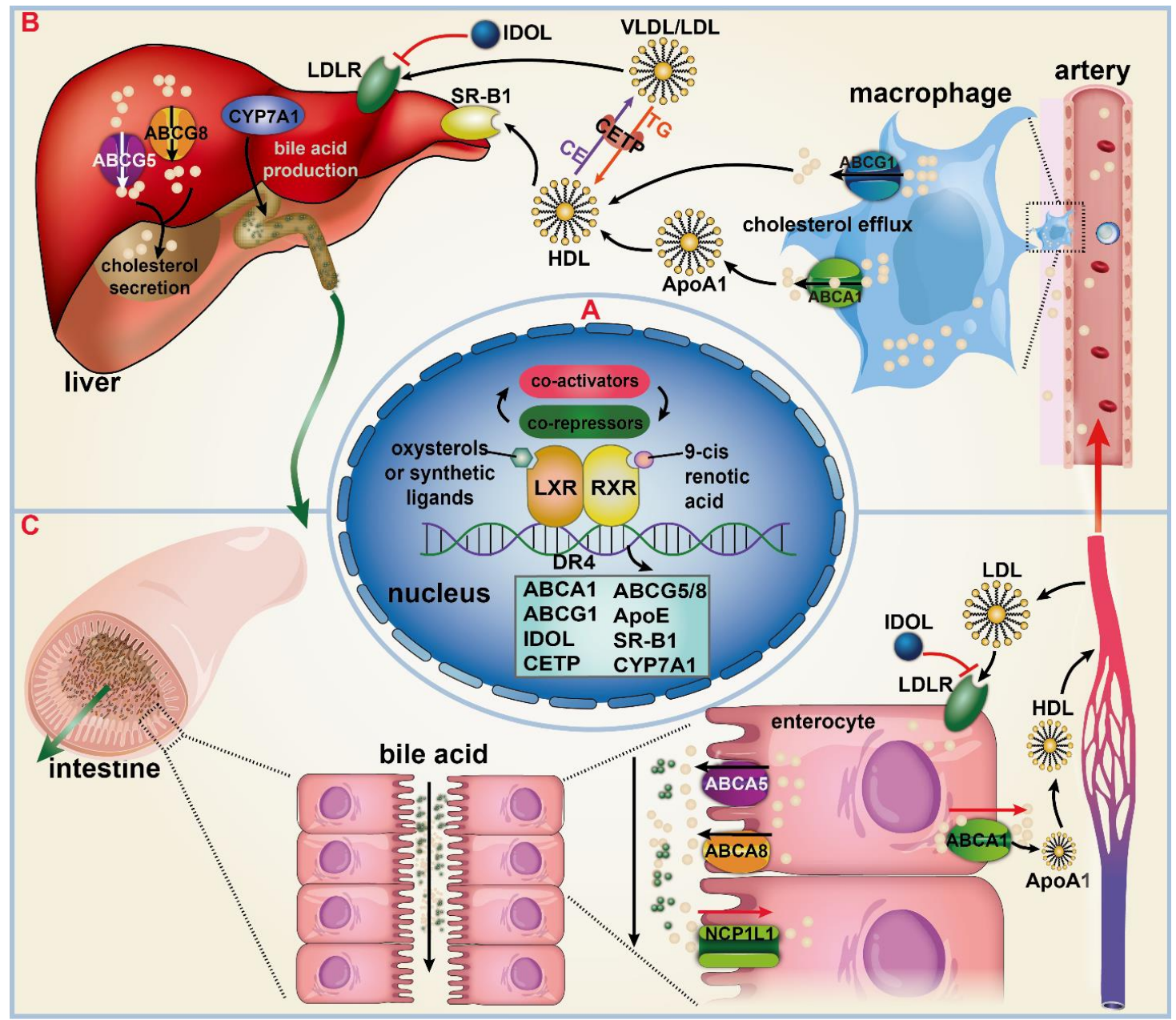

Figure 1. LXR-RXR heterodimers and the actions of LXRs in RCT and TICE. A. This diagram summarizes how the LXR-RXR heterodimer regulates the transcription of its target genes. The LXR-RXR heterodimer binds to an LXR response element (LXRE), a specific DNA sequence represented by a repeated AGGTCA sequence that is separated by four nucleotides (a DR4 response element). When unbound, the LXR-RXR heterodimer remains bound to the promoter region of its target genes in a complex with co-repressors, such as SMRT and NCoR. Once bound to an agonist, the conformation of the LXR-RXR complex changes, leading to the release of its nuclear receptor co-repressors and the recruitment of nuclear receptor co-activators, such as ASC2 and EP300. B. This diagram summarizes the actions of LXRs in reverse cholesterol transport (RCT), which are described in the LXRs and reverse cholesterol transport section. However, the activation of LXRs also promotes the expression of CETP. VLDL and LDL particles bearing ApoB can unload cholesterol from HDL particles through the action of CETP. The blockade of CETP can thus augment HDL levels, but the process is not yet known to produce a clinical benefit. C. This diagram summarizes the actions of LXRs in trans-intestinal cholesterol efflux (TICE), which are illustrated in the LXRs and trans-intestinal cholesterol excretion section. Abbreviations: RXR, retinoid X receptor; ABCA1, ATP-binding cassette subfamily A type 1; HDL, high-density lipoprotein; LDLR, lowdensity lipoprotein receptor; SR-B1, scavenger receptor class B type 1; CYP7A1, cholesterol 7-a-hydroxylase; IDOL, inducible degrader of the LDL receptor; CETP, cholesteryl ester transfer protein; CE, cholesteryl ester; TG, transfers triglyceride. 
the cholesterol is internalized, trafficked across the cell, and secreted into the lumen of the small intestine (Brufau et al., 2011; Marshall et al., 2014). Several direct LXR target genes are closely associated with the TICE pathway, including $A B C A 1, A B C G 5$ and ABCG8. In addition, the activation of LXRs by agonists has been shown to stimulate TICE in mice by $100 \%$ (van der Veen et al., 2009).

At the cellular level, lipoprotein receptors that are expressed on the basolateral surface of enterocytes, such as LDLRs, take up circulating cholesterol. Then, transporters on the apical surface, such as ABCG5 and ABCG8, secrete cholesterol into the lumen (Hong and Tontonoz, 2014). Complementing this pathway, NiemannPick C1-like protein (NPC1L1), another transporter that is expressed on the apical surface, plays a significant role in the absorption of dietary cholesterol from the lumen (Altmann et al., 2004). Moreover, cholesterol can also be transferred to ApoA1 on the basolateral membrane via $A B C A 1$, thus contributing to HDL formation (Pannu et al., 2013) (Figure 1C).

\section{Downstream genes of LXRs in the regulation of cholesterol transport}

\section{$A B C A 1$ and $A B C G 1$}

$A B C A 1$, an integral membrane transporter, plays a major role in $\mathrm{HDL}$ formation and was originally discovered in patients with Tangier disease. These patients display near-absent HDL levels and a loss of ABCA1 function (Bodzioch et al., 1999). ABCA1 facilitates the movement of cell cholesterol and phospholipids onto exchangeable Apos, in particular ApoA1, to initiate the formation of HDL particles (Oram and Heinecke, 2005). Studies using tissue-specific ABCA1 knockout mice have shown that hepatocyte deletion results in a nearly $80 \%$ decrease in plasma HDL cholesterol levels (Brunham et al., 2009), with enterocyte deletion accounting for $30 \%$ of the decrease (Brunham et al., 2006), and adipocyte deletion causing $15 \%$ of the decrease (Chung et al., 2011). In contrast, the expression of ABCA1 in macrophages and other hematopoietic cells does not contribute to plasma HDL cholesterol levels (Haghpassand et al., 2001). ABCA1 is transcriptionally induced by LXRs, which are activated by the accumulation of oxysterols (Costet et al., 2000). Moreover, the treatment of mice with synthetic LXR agonists upregulated ABCA1 expression and increased plasma HDL cholesterol levels, thus establishing an essential role for LXRs in cholesterol efflux via ABCA1 (Costet et al., 2000).

In contrast with $A B C A 1$, another $A B C$ transporter, $A B C G 1$, has been shown to mediate cholesterol efflux to HDL particles but not lipidfree Apos (Kennedy et al., 2005). ABCA1 and $A B C G 1$ thus have complementary roles in mediating cholesterol efflux to HDL. Abcg 1/mice exhibit a striking lipid phenotype of cholesterol accumulation in macrophages in multiple tissues, particularly in the lungs. However, unlike $A B C A 1$, the role of $A B C G 1$ in atherosclerosis progression is quite complex, and $A B C G 1$ alone does not markedly influence atherosclerosis in mice (Tarling, 2013; Westerterp et al., 2014). When given a high-fat diet, the loss of total body ABCG1 transport does not significantly promote atherosclerosis, and the loss of macrophage ABCG1 in the context of the $\mathrm{Ldll}^{\mathrm{I}^{-}}$or $\mathrm{ApoE^{-/- }}$ atherosclerosis models has been controversially reported to be either pro- or antiatherogenic (Baldan et al., 2006; Lammers et al., 2009; Out et al., 2006; Ranalletta et al., 2006; Vaughan and Oram, 2005; Westerterp et al., 2014). Interestingly, the loss of $A B C A 1$ and $A B C G 1$ in mice results in a synergistic increase in tissue lipid accumulation (Out et al., 2008; Yvan-Charvet et al., 2007), and the induction of ABCA1 and ABCG1 expression by cholesterol loading and synthetic LXR agonists suggests a coordinated role for these two transporters in managing cellular cholesterol overload (Aye et al., 2010).

\section{ABCG5 and ABCG8}

Two additional members of the $A B C$ transporter family, ABCG5 and ABCG8, form the obligate heterodimer that limits intestinal absorption and facilitates the biliary secretion of cholesterol and phytosterols (Graf et al., 2002; Yu et al., 2014). Consistent with these functions, ABCG5 and ABCG8 are expressed almost exclusively on the brush border membranes of enterocytes and in the canalicular membranes of hepatocytes (Yu et al., 2014). LXRa is regarded as the major regulator of $A B C G 5$ and $A B C G 8$ mRNA expression, and the LXR agonist T0901317 markedly upregulates ABCG5 and ABCG8 expression in the small intestine and liver of wild type but not LXRa knockout mice (GonzalezGranillo et al., 2012; van der Veen et al., 2007). Mutations in either of these two genes results in sitosterolemia, which causes the accumulation of plant sterols and cholesterol in the circulation, 
leading to premature cardiovascular diseases (Berge et al., 2000). However, the overexpression of ABCG5 and ABCG8 in mice retards dietinduced atherosclerosis by reducing circulating and hepatic cholesterol (Wilund et al., 2004).

\section{ApoE}

ApoE is a major component of very low-density lipoproteins (VLDLs), remnant lipoproteins and HDL. ApoE on the surface of lipoproteins serves as a natural ligand for many receptors, including LDLRs, LDLR-related proteins, VLDL receptors and heparin sulfate proteoglycans ( $\mathrm{Li}$ and Liu, 2014). ApoE-containing HDL participates in cholesterol efflux and contributes to the maintenance of plasma and tissue cholesterol homeostasis (Mahley and Rall, 2000). ApoE is mainly synthesized by the liver but is also produced by the brain, kidney, adipocytes, smooth muscle cells and macrophages ( $\mathrm{Li}$ and Liu, 2014). Interestingly, LXR activation of ApoE is tissue specific and stimulates ApoE expression in macrophages and adipose tissue but not in the liver (Laffitte et al., 2001). Several other genes that encode Apos, including ApoC1, ApoC2, ApoC4 and ApoD, are also LXRresponsive (Hong and Tontonoz, 2014).

\section{$S R-B 1$}

SR-B1 is a physiologically relevant lipoprotein receptor that regulates the selective uptake of lipids in tissues such as the liver, adrenal glands and ovaries. Studies have reported that SR-B1 also localizes to atherosclerotic plaques and the endothelium (Hirano et al., 1999; Yuhanna et al., 2001). SR-B1 is believed to play a major role in the delivery of HDL-derived cholesteryl esters to the liver (Swarnakar et al., 1999). In humans, the $S R-B 1$ gene (SCARB1) is located on chromosome 12 (12q24.31). The SR-B1 gene contains an LXRE region that responds to oxysterol-stimulated LXR activation (Malerod et al., 2002).

\section{CYP7A1}

CYP7A1 belongs to the large family of P450 cytochrome proteins and is the rate-limiting enzyme during the synthesis of bile acid in the liver, which occurs through a classic pathway by producing 7-a-hydroxycholesterol (Iwanicki et al., 2015). In humans, the CYP7A1 gene is located on chromosome 8 (8q11.12) and consists of 6 exons and 5 introns (Noshiro and Okuda, 1990). However, the regulation of CYP7A1 by cholesterol varies across species. Although rodents possess an LXRE in CYP7A1, humans do not (Goodwin et al., 2003). Moreover, LXRa, but not $L X R \beta$, is regarded as the major regulator of CYP7A1 mRNA expression in the mouse liver (Peet et al., 1998b).

\section{Cholesteryl ester transfer protein (CETP)}

CETP is a protein that transfers triglyceride (TG) from VLDL or LDL and in exchange for cholesteryl ester (CE) from HDL, and CETP has also been documented to be regulated by LXRs (Barter et al., 2003; Honzumi et al., 2010; Tall et al., 2008). CETP is synthesized in the liver and secreted into the plasma, and its activity influences the atherogenicity of the lipoprotein profile and cholesterol efflux in macrophages (Tall et al., 2008). In humans, CETP deficiency characteristically exhibits high HDL and low LDL levels (Brown et al., 1989; Inazu et al., 1994), but the correlation of plasma CETP level with atherosclerosis remains controversial and has not yet been clearly demonstrated in studies involving human populations (Dullaart et al., 2007; Quintao, 2016). Some species, such as rats and mice, do not express CETP, and transfer of cholesterol and CE to the liver mainly via HDL (Kingwell et al., 2014). Therefore, CETP-containing species, such as hamsters, monkeys, and ApoB/CETP double-transgenic mice, have been used to evaluate the effects of CETP expression on lipid metabolism and atherosclerosis development (Honzumi et al., 2010; Kingwell et al., 2014). Numerous studies suggest that CETP may have pro- or antiatherogenic properties depending upon the pathophysiological settings, and whether the CETP inhibition-induced lipoprotein changes exert anti-atherogenic activities remains a matter of debate (Dullaart et al., 2007; Ghosh and Ghosh, 2012; Quintao, 2016). LXRa has an essential role in the induction of CETP, whereas LXR $\beta$ activation has only a minor effect (Honzumi et al., 2010). T0901317 enhanced plasma CETP activity and resulted in increased non-HDL and decreased HDL, which suggests that the activation of CETP may potentially be an unwelcome side effect of pan-LXR agonists (Honzumi et al., 2010).

\section{Inducible degrader of the LDLR (IDOL)}

IDOL is an E3 ubiquitin ligase that mediates the ubiquitination and degradation of LDLR. IDOL expression is controlled at the transcriptional level by LXRs, which are independent of sterol regulatory element-binding protein (SREBP) and 
proprotein convertase subtilisin/kexin type 9 (PCSK9) (Zhang et al., 2012). When cellular cholesterol levels rise, oxysterols are formed and serve as ligands for LXRs (Janowski et al., 1999). Activated LXRs induce IDOL production, which further limits the uptake of exogenous cholesterol by the LDLR pathway (Zhang et al., 2012). Synthetic LXR agonists are powerful regulators of RCT that inhibit the development of atherosclerosis in mice (Naik et al., 2006). However, synthetic LXR agonists also induce hepatic IDOL expression, reduce LDLR levels and raise plasma LDL levels in primates, which are undesirable side effects of LXR agonists (Hong et al., 2014). In addition, the effects of the LXR-IDOL pathway on LDLR protein levels are both tissue- and species-specific. In mice, LXR agonists induce IDOL expression in peripheral tissues but not in the liver and do not change plasma LDL levels. By contrast, LXR agonists raise plasma LDL cholesterol levels in primates through an IDOL-dependent mechanism, and IDOL is highly induced by LXR agonists in human hepatocyte cell lines (Hong et al., 2014; Zelcer et al., 2009). Therefore, the LXR-IDOL pathway may be a potential target for the modulation of LDL cholesterol levels, and IDOL inhibition may mitigate the undesirable effects of synthetic LXR agonists on plasma LDL cholesterol levels in humans.

\section{Promoting the cholesterol removal activity of LXR agonists against atherosclerosis}

Atherosclerosis is a chronic inflammatory disease of the vasculature that is characterized by lipid accumulation and plaque development within arteries. LXRs function as whole-body cholesterol sensors, and their activation contributes to protection against atherosclerosis. $L X R \alpha / \beta$ double-knockout mice exhibited increased aortic foam cell accumulation after 18 months of being fed a normal chow diet (Schuster et al., 2002). In contrast, the activation of LXRs resulted in the removal of cholesterol from the body and the amelioration of plasma lipoprotein levels by mobilizing cholesterol from the periphery, reducing cholesterol uptake in the intestine, promoting cholesterol hepatic/intestinal excretion and enhancing its conversion to bile acids (Bonamassa and Moschetta, 2013).

\section{Oxysterols and synthetic LXR agonists}

Oxysterols and synthetic LXR agonists are powerful regulators of RCT and TICE that inhibit the development of atherosclerosis in mice. The natural ligands of LXRs are oxygenated forms of cholesterol and certain bile acids, such as 22(R)hydroxycholesterol (22R-OHC), 20(S)-hydroxycholesterol (20S-OHC), 24(S)-hydroxycholesterol (24S-OHC), 25-hydroxycholesterol (25-OHC), 27-hydroxycholesterol (27-OHC), and 24(S),25-epoxycholesterol (24S,25-EC) (Beyea et al., 2012; Jakobsson et al., 2012; Pannu et al., 2013). The rank order of serum LXR ligand oxysterols levels is $27-\mathrm{OHC}>22 \mathrm{R}-\mathrm{OHC}>25$ $\mathrm{OHC}(\mathrm{ng} / \mathrm{mg})$ in healthy populations (Ikegami et al., 2012; Koschack et al., 2009), and the order of the ability to activate LXRs is $27-\mathrm{OHC}>24 \mathrm{~S}$, $25-\mathrm{EC}>22 \mathrm{R}-\mathrm{OHC}>20 \mathrm{~S}-\mathrm{OHC}>24 \mathrm{~S}-\mathrm{OHC}>$ 25-OHC (nM or $\mu \mathrm{M})$ (Beltowski, 2008; Fu et al., 2001; Janowski et al., 1996). The development of LXR agonists can be traced back to the 2000s, as well as the discovery of the first two agonists, T0901317 and GW3965 (Collins et al., 2002) (Figure 2). These compounds are full agonists for both $L X R \alpha$ and $L X R \beta$ and show antiatherosclerotic effects. Unfortunately, their positive effects on atherosclerosis are countered by the induction of hepatic lipogenesis, which leads to hypertriglyceridemia and liver steatosis (Schultz et al., 2000), and other undesirable side effects of LXR agonists, such as the degradation of hepatic LDLRs through the LXR-IDOL pathway (Hong et al., 2014).

In addition to their central role in cholesterol homeostasis, LXRs are also important regulators of hepatic lipogenesis. In response to natural or synthetic ligands, the activation of LXRs induces the expression of two master transcription factors, sterol regulatory element-binding protein-1C (SREBP-1C) and carbohydrate response element-binding protein (ChREBP), which control hepatic lipogenesis and triglyceride secretion and cause hypertriglyceridemia (Faulds et al., 2010). Although both LXRa and LXR $\beta$ are capable of inducing hepatic lipogenesis, studies in LXR knockout mice have suggested that LXRa is the dominant isoform in this pathway (Repa et al., 2000). Therefore, the specific targeting of LXR $\beta$ has been proposed to achieve anti-atherosclerotic benefits while avoiding hepatic lipogenesis and consequent hepatosteatosis.

Members of the first generation of synthetic LXR agonists, including T0901317 and GW3965, were unsuitable for clinical development due to their pleotropic effects, but these compounds are valuable to the research community. In recent 


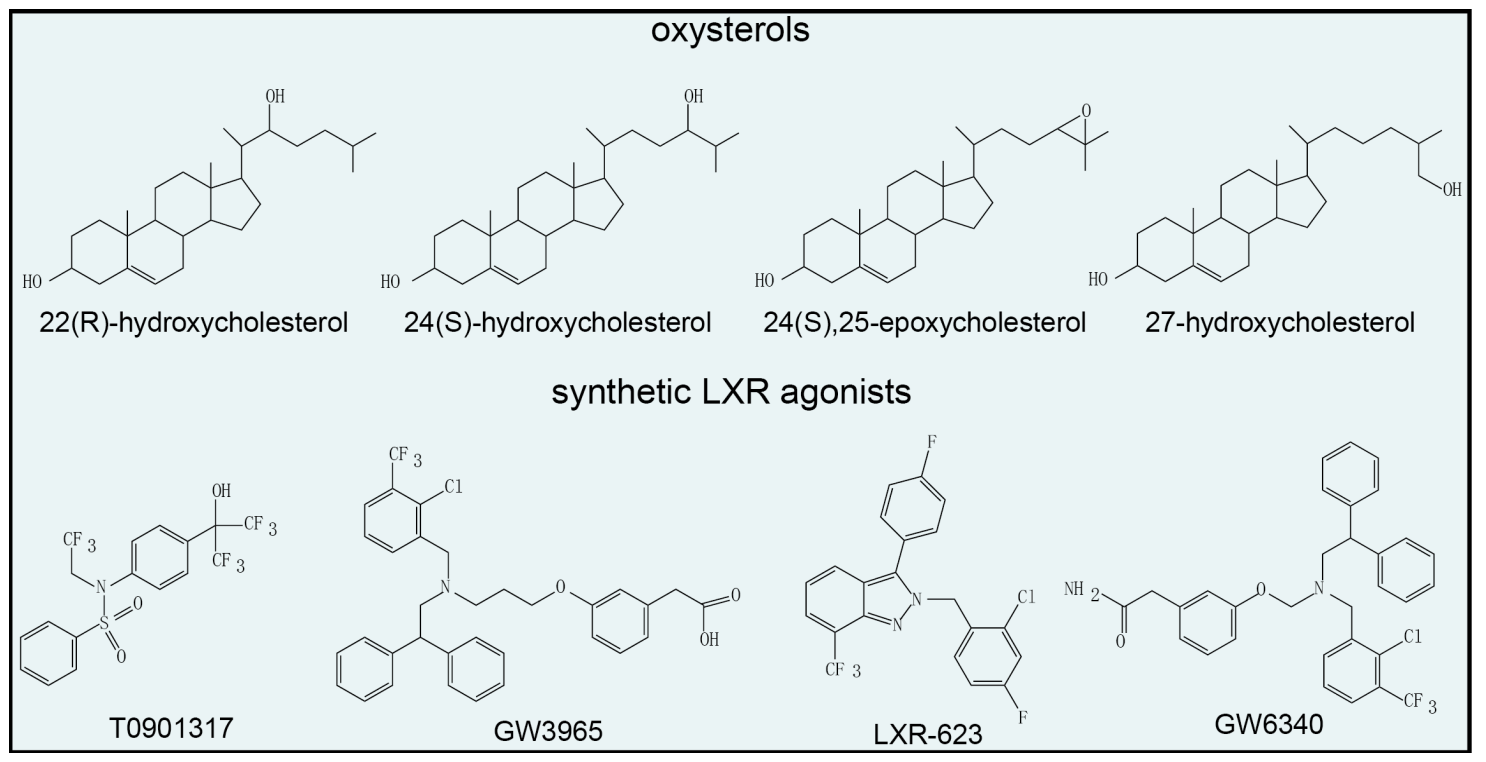

Figure 2. Molecular structures of oxysterols and synthetic LXR agonists.

years, several studies have been devoted to identifying new synthetic LXR agonists. $N, N-$ dimethyl-3 $\beta$-hydroxy-cholenamide (DMHCA) represents a gene-selective LXR modulator that mediates the potent transcription activation of ABCA1 gene expression while exhibiting minimal effects on SREBP-1c both in vitro and in vivo in mice (Quinet et al., 2004). Moreover, AZ876 is a newly developed dual $L X R \alpha / \beta$ partial agonist that has been shown to reduce atherosclerosis in mice without affecting liver or plasma TG levels when administered at low doses (van der Hoorn et al., 2011). However, these agonists have been evaluated in clinical trials, and whether they are safe for humans requires further investigation. LXR-623 (WAY-252623), an LXR $/ \beta$ partial agonist, was the first LXR-targeted compound to enter clinical trials, and published data described a dose-dependent increase in ABCA1 and ABCG1 expression in peripheral blood cells of healthy individuals (Katz et al., 2009). LXR agonists could cross the blood-brain barrier and exert advantageous effects on the central nervous system (CNS) (e.g., effects against neuroinflammation and Alzheimer's disease) ( $\mathrm{Li}$ et al., 2010; Stukas et al., 2012; Wu et al., 2016). Unfortunately, the published Phase I clinical results of LXR-623 suggested that further development of the compound was discontinued due to adverse CNS effects, and it is still unknown whether the adverse CNS observations were off-target effects specific to LXR-623 or were related to LXR modulation in the brain (Hong and Tontonoz, 2014; Katz et al., 2009; Li et al., 2010). To date, similar adverse CNS events in humans have not been reported for other LXR agonists. Moreover, several other compounds, including CS8080, BMS-779788 (XL-652) and BMS-852927 (XL-041), entered Phase 1 clinical trials and exhibited limited success but were terminated due to their unexpected adverse effects (Loren et al., 2013) (Table 1). More detailed reviews of those patented compounds can be found elsewhere ( $\mathrm{Li}$ et al., 2010; Loren et al., 2013). In addition, the intestine-specific $L X R \alpha / \beta$ agonist GW6340, an ester form of the systemic $L X R \alpha / \beta$ agonist GW3965, was discovered. GW6340 significantly upregulates $A B C A 1, A B C G 5$ and $A B C G 8$ expression in the small intestine but not in the liver, and it avoids the hypertriglyceridemia effects induced by systemic LXR ligands (Yasuda et al., 2010).

Interestingly, in addition to the genomic effects of LXRs on cholesterol transport, several studies have reported that LXRs also play non-genomic roles in macrophage cholesterol homeostasis. Huwait and colleagues demonstrated that the JNK/C-Jun/AP-1 pathway participates in the LXR 
Table 1. The synthetic LXR agonists.

\begin{tabular}{|c|c|c|c|c|c|}
\hline $\begin{array}{l}\text { Synthetic } \\
\text { agonists }\end{array}$ & Company & Type & ClinicalTrials.gov Identifier & Comments & References \\
\hline T0901317 & $\begin{array}{l}\text { Tularik } \\
\text { (now Amgen) }\end{array}$ & Pan-agonist & None & $\begin{array}{l}\text { The first described } \\
\text { synthetic LXR agonist } \\
\text { Used as a tool compound } \\
\text { in research }\end{array}$ & $\begin{array}{l}\text { (Schultz et al., } \\
2000)\end{array}$ \\
\hline GW3965 & $\begin{array}{l}\text { GlaxoSmithKli } \\
\text { ne }\end{array}$ & Pan-agonist & None & $\begin{array}{l}\text { Used as a tool compound } \\
\text { in research }\end{array}$ & (Collins et al., 2002) \\
\hline $\begin{array}{l}\text { LXR-623 } \\
\text { (WAY-252 } \\
623)\end{array}$ & $\begin{array}{l}\text { Wyeth } \\
\text { (now Pfizer) }\end{array}$ & $\begin{array}{l}\text { High affinity for } \\
\text { LXR } \text { but } \\
\text { partial LXRa } \\
\text { agonist }\end{array}$ & $\begin{array}{l}\text { NCT00366522 (Phase 1, } \\
\text { completed) } \\
\text { NCT00385489 (Phase 1, } \\
\text { completed) } \\
\text { NCT00379860 (Phase 1, } \\
\text { terminated) }\end{array}$ & $\begin{array}{l}\text { The first LXR-targeted } \\
\text { compound to enter } \\
\text { clinical trials } \\
\text { Potential treatment of } \\
\text { atherosclerosis and } \\
\text { dyslipidemia } \\
\text { Trial was terminated due } \\
\text { to adverse CNS effects } \\
\text { (150 and } 300 \mathrm{mg} / \text { day) }\end{array}$ & $\begin{array}{l}\text { (Hong and } \\
\text { Tontonoz, 2014; } \\
\text { Katz et al., 2009; Li } \\
\text { et al., 2010) }\end{array}$ \\
\hline AZ876 & None & $\begin{array}{l}\mathrm{LXR \alpha} / \beta \text { partial } \\
\text { agonist }\end{array}$ & None & $\begin{array}{l}\text { WIPO Patent Application } \\
\text { WO200607336 } \\
\text { Anti-atherosclerosis } \\
\text { effects in mice without } \\
\text { affecting triglyceride } \\
\text { levels when administered } \\
\text { at low doses }\end{array}$ & $\begin{array}{l}\text { (Cannon et al., } \\
\text { 2015; van der } \\
\text { Hoorn et al., 2011) }\end{array}$ \\
\hline GW3640 & $\begin{array}{l}\text { GlaxoSmithKli } \\
\text { ne }\end{array}$ & $\begin{array}{l}\text { Intestinal- } \\
\text { specific LXR } \\
\text { agonist }\end{array}$ & None & $\begin{array}{l}\text { Promoting macrophage } \\
\text { RCT in vivo in mice }\end{array}$ & $\begin{array}{l}\text { (Yasuda et al., } \\
2010 \text { ) }\end{array}$ \\
\hline CS8080 & $\begin{array}{l}\text { Daichii } \\
\text { Sankyo }\end{array}$ & Not known & $\begin{array}{l}\text { NCT00613431 (Phase 1, } \\
\text { completed) } \\
\text { NCT00796575 (Phase 1, } \\
\text { terminated) }\end{array}$ & $\begin{array}{l}\text { By late } 2008 \text {, the project } \\
\text { was terminated due to } \\
\text { undisclosed safety } \\
\text { concerns }\end{array}$ & $\begin{array}{l}\text { (Li et al., 2010; } \\
\text { Loren et al., 2013) }\end{array}$ \\
\hline $\begin{array}{l}\text { BMS-7797 } \\
88 \\
(X L-652)\end{array}$ & $\begin{array}{l}\text { Exelixis and } \\
\text { Bristol-Myers } \\
\text { Squibb }\end{array}$ & Not known & $\begin{array}{l}\text { NCT00836602 (Phase 1, } \\
\text { completed) }\end{array}$ & $\begin{array}{l}\text { Potential treatment of } \\
\text { atherosclerosis } \\
\text { Proved safety but data } \\
\text { have not yet been } \\
\text { reported }\end{array}$ & $\begin{array}{l}\text { (Li et al., 2010; } \\
\text { Loren et al., 2013) }\end{array}$ \\
\hline $\begin{array}{l}\text { BMS-8529 } \\
27 \\
(\mathrm{XL}-041)\end{array}$ & $\begin{array}{l}\text { Exelixis and } \\
\text { Bristol-Myers } \\
\text { Squibb }\end{array}$ & Not known & $\begin{array}{l}\text { NCT01651273 (Phase 1, } \\
\text { terminated) }\end{array}$ & $\begin{array}{l}\text { Potential treatment of } \\
\text { dyslipidemia } \\
\text { Terminated for } \\
\text { undisclosed reasons in } \\
2013\end{array}$ & $\begin{array}{l}\text { (Li et al., 2010; } \\
\text { Loren et al., 2013) }\end{array}$ \\
\hline
\end{tabular}

agonist-mediated induction of $A p o E$ and $A B C A 1$ expression, which are implicated in the control of macrophage cholesterol efflux (Huwait et al., 2011). Moreover, Buono and colleagues reported that the synthetic and natural LXR agonists, T0901317 and 22-OHC, downregulate macrophage LDL uptake by inhibiting the fluidphase pinocytosis of native LDL (Buono et al., 2007). Therefore, the activation of LXR transcription factors may be atheroprotective via other novel mechanisms.

\section{Mitochondrial translocator protein (TSPO)}

The mitochondrial $18 \mathrm{kDa}$ TSPO [peripheral benzodiazepine receptor (PBR)] is located at the contact sites between the outer and inner mitochondrial membranes and may be therapeutically useful for reducing atherosclerosis (Allen et al., 2013). TSPO has five transmembrane domains and a high affinity for the cholesterol/interaction recognition amino acid consensus (CRAC)-binding C-terminal domain (Allen et al., 2013). TSPO knockdown induced the arrest of mitochondrial cholesterol transport. In contrast, the activation of TSPO by its ligands plays a role in fasting metabolism by reducing 
lipogenesis and hepatosteatosis in obese mice (Allen et al., 2013; Gut et al., 2013). Moreover, recent work by Taylor et al. showed that TSPO overexpression or ligation induced the expression of $L X R \alpha$, peroxisome proliferationactivated receptor $\alpha$ (PPAR $\alpha)$, ApoE, ABCA1, and $A B C G 4$, but not ABCG1, and contributed to the increased efflux of cholesterol to ApoA1 and HDL into macrophages. In addition, the overexpression or ligation of TSPO also caused a decline in macrophage total neutral lipid mass without inducing lipogenesis and effectively prevented foam cell formation by limiting cholesterol esterification following exposure to acetylated LDL (Taylor et al., 2014). Mechanistically, the coordinated induction of PPAR a and LXR $\alpha$ by TSPO may be a key factor in abrogating the side effects associated with the activation of $L X R \alpha$ by agonists, such as T0901317. TSPO ligand treatments have been previously reported to promote mitochondrial 27$\mathrm{OHC}$ production (a natural ligand of LXRs, as mentioned above) (Tsankova et al., 1996); however, whether this effect contributes to LXR activation remains unknown. Altogether, targeting mitochondrial TSPO activity or maintaining its function could be therapeutically useful for reducing atherosclerosis, and determining whether it will be useful in primates or humans warrants further investigation.

\section{Heme and metformin}

Mhem is a novel adaptive macrophage phenotype that was discovered in human plaques (Boyle et al., 2009). Mhem exhibits coordinated properties, including increased heme oxygenase-1 $(\mathrm{HO}-1)$ expression, reduced oxidative stress, a suppressed inflammatory response, increased lipid export and resistance to foam cell formation (Boyle et al., 2009). Recent work by Wan et al. has shown that the concentration of heme or metformin drives macrophages to exhibit the Mhem phenotype (Wan et al., 2013).

Metformin is a relatively safe oral hypoglycemic agent that is effectively used to treat type 2 diabetes mellitus without causing hypoglycemia (El Messaoudi et al., 2011). Metformin also shows cardioprotective effects by improving myocardial remodeling and protecting against ischemia-reperfusion injury (El Messaoudi et al., 2011). In addition, Wan et al. demonstrated that a pathophysiological concentration of heme (10 $\mu \mathrm{mol} / \mathrm{L})$ and a pharmacologically relevant concentration of metformin (also $10 \mu \mathrm{mol} / \mathrm{L}$ ) increased activating transcription factor 1 (ATF1) expression via the activation of 5'-AMP-activated protein kinase (AMPK). The AMPK-ATF1 pathway drives the transcriptional co-induction of $\mathrm{HO}-1$ and LXR $\beta$, which allows the interlinking of antioxidant activity resistance to foam cell formation and macrophage deactivation (Wan et al., 2013). Accordingly, AMPK-ATF1 pathway modulation by metformin may provide an effective therapeutic strategy for the treatment of atherosclerosis. Whether this pathway protects against vascular disease in vivo and what downstream genes of LXR $\beta$ are induced by metformin remain to be determined.

\section{Other potential $L X R$ agonists}

In addition to the previously mentioned LXR agonists, other mediators of LXRs also confer protection against atherosclerosis (Table 2). Fibroblast growth factor-21 (FGF21), a member of the FGF superfamily, is an important endogenous regulator of systemic glucose and lipid metabolism. Elevated serum FGF21 levels have been reported in subjects with coronary heart disease and carotid artery plaques (Habegger et al., 2013). Recent work by Lin et al. has demonstrated that FGF21 promotes cholesterol efflux by upregulating $A B C A 1$ through the extracellular signal-regulated kinase 1 and 2 (ERK1/2)/PPARY/LXRa pathway in THP1 macrophage-derived foam cells in a doseand time-dependent manner (Lin et al., 2014). Soluble guanylyl cyclase (sGC) is a key intracellular signaling acceptor of endothelial nitric oxide synthase-derived nitric oxide (NO) in smooth muscle cells (Angelone et al., 2008). Tsou et al. reported that the activation of sGC by 3-(5'hydroxymethyl-2'furyl)-1-benzyl indazole (YC-1) leads to the LXRa-dependent upregulation of $A B C A 1$ in macrophages and may confer protection against atherosclerosis (Tsou et al., 2014). In addition, Campia and colleagues observed that cardioactive glycosides, such as digoxin and ouabain, activate LXRs and increase the expression of $A B C A 1$ but not $A B C G 1$ (Campia et al., 2012). Accordingly, glycosides may be novel therapeutic targets for use against atherosclerosis. However, little is known about the anti-atherogenic biological interaction between SGC activation and LXRa. Whether the activation of LXR $\alpha$ by FGF21, YC-1 and glycosides induces hepatic lipogenesis may warrant further investigation. 
Table 2. Potential LXR agonists involved in anti-atherogenic effects.

\begin{tabular}{|c|c|c|c|}
\hline LXR agonists & Experimental models & Mechanisms & References \\
\hline TSPO & Human THP-1 monocytes & $\begin{array}{l}\text { Inducing the expression of } L X R \alpha, P P A R a, A p o E \text {, } \\
\text { ABCA1 and ABCG4 }\end{array}$ & Taylor et al., 2014 \\
\hline Metformin & Human blood-derived macrophages & $\begin{array}{l}\text { Promoting HO-1 and LXR } \beta \text { expression through } \\
\text { the AMPK-ATF1 pathway }\end{array}$ & Wan et al., 2013 \\
\hline FGF21 & $\begin{array}{l}\text { THP-1 macrophage-derived foam } \\
\text { cells }\end{array}$ & $\begin{array}{l}\text { Upregulating ABCA } 1 \text { through the ERK1/2/ } \\
\text { PPARY/LXRa pathway }\end{array}$ & Lin et al., 2014 \\
\hline YC-1 & $\begin{array}{l}\text { TIB-67 cells and ApoE KO mice } \\
\text { injected with YC-1 }\end{array}$ & Promoting the expression of $A B C A 1$ and $L X R \alpha$ & Tsou et al., 2014 \\
\hline Digoxin & $\begin{array}{l}\mathrm{H} 9 \mathrm{c} 2 \text { cells and FVB male mice } \\
\text { injected with digoxin }\end{array}$ & Promoting the expression of ABCA 1 and LXRs & Campia et al., 2012 \\
\hline $\begin{array}{l}\text { Lactobacillus } \\
\text { plantarum } \\
\text { PCS } 26\end{array}$ & $\begin{array}{l}\text { Human small intestinal fetal epithelial } \\
\text { cells }\end{array}$ & $\begin{array}{l}\text { Upregulating ABCG5/ABCG8 and } \\
\text { downregulating NPC1L1 expression }\end{array}$ & Gorenjak et al., 2014 \\
\hline Pravastatin & Human Hep3B cells & $\begin{array}{l}\text { Promoting CYP7A } 1 \text { and ABCG5/ABCG8 } \\
\text { expression through the PPARY/LXRa pathway }\end{array}$ & Byun et al., 2014 \\
\hline
\end{tabular}

TSPO, translocator protein; HO-1, heme oxygenase 1; ATF1, activating transcription factor 1; AMPK, 5'-AMP-activated protein kinase; ERK1/2, extracellular signal-regulated kinases 1 and 2; YC-1, 3-(5'hydroxymethyl-2'furyl)-1-benzyl indazole

Several studies have shown that probiotic bacteria exert positive effects on hypercholesterolemia by lowering serum cholesterol and improving lipid profiles, which in turn leads to a reduced risk of atherosclerosis and coronary heart disease (Sanders, 2000). Lactobacillus plantarum PCS26 may act as an LXR agonist and may therefore promote ABCG5/ABCG8 expression and downregulate NPC1L1 expression in small intestine cells (Gorenjak et al., 2014). Accordingly, Lactobacillus plantarum PCS26 has the potential to promote biliary cholesterol efflux and inhibit intestinal absorption, but it also warrants study in in vivo clinical trials for further assessment. Statins are extremely effective at reducing cardiovascular risk, as demonstrated in clinical studies that have confirmed the inhibition of the onset and progression of atherosclerosis (Zhao et al., 2015). Byun et al. reported that pravastatin enhances hepatic bile acid synthesis via the PPARY-LXRa-CYP7A1 pathway and activates PPARY-LXRa-ABCG5/ABCG8, which excretes cholesterol into bile (Byun et al., 2014). In addition, Ginnarelli and colleagues reported that LXR-623 significantly reduces the progression of atherosclerosis and induces plaque regression when used in combination with simvastatin, a finding that may drive the future development of novel anti-atherosclerotic therapeutic approaches (Giannarelli et al., 2012).
Generally speaking, the potential LXR agonists mentioned above may exert anti-atherogenic activities via the stimulation of LXRs. However, as with statins, their anti-atherogenic effects may be largely or partially related to LXR activation. Therefore, the use of cells or animals with genetic alterations related to LXRs may reveal whether LXR-dependent pathways play major roles in the anti-atherosclerosis effects exerted by those agents.

\section{Anti-inflammatory activity of LXRs against atherosclerosis \\ Macrophages \\ Inflammation plays a significant role in the development of atherosclerosis. In addition to their beneficial effects on macrophage cholesterol efflux, LXRs may also modulate atherosclerosis through their anti-inflammatory roles (Steffensen et al., 2013; Zelcer and Tontonoz, 2006). Mechanistically, these effects of LXRs are attributed to the nuclear inhibition of nuclear factor $\mathrm{kB}(\mathrm{NF}-\mathrm{kB})$ signaling via transrepression (Calkin and Tontonoz, 2010; Ghisletti et al., 2007). Interestingly, ligand-bound LXRs are not recruited to LXREs in pro- inflammatory gene promoters but are conjugated to a small ubiquitin-like modifier (SUMO) protein. In the promoters of NF-kB target genes, SUMOylated LXRs prevent the removal of the NCoR/SMRT co-repressor from NF-KB, which results in the maintenance of downstream inflammatory genes, such as matrix metallo-}



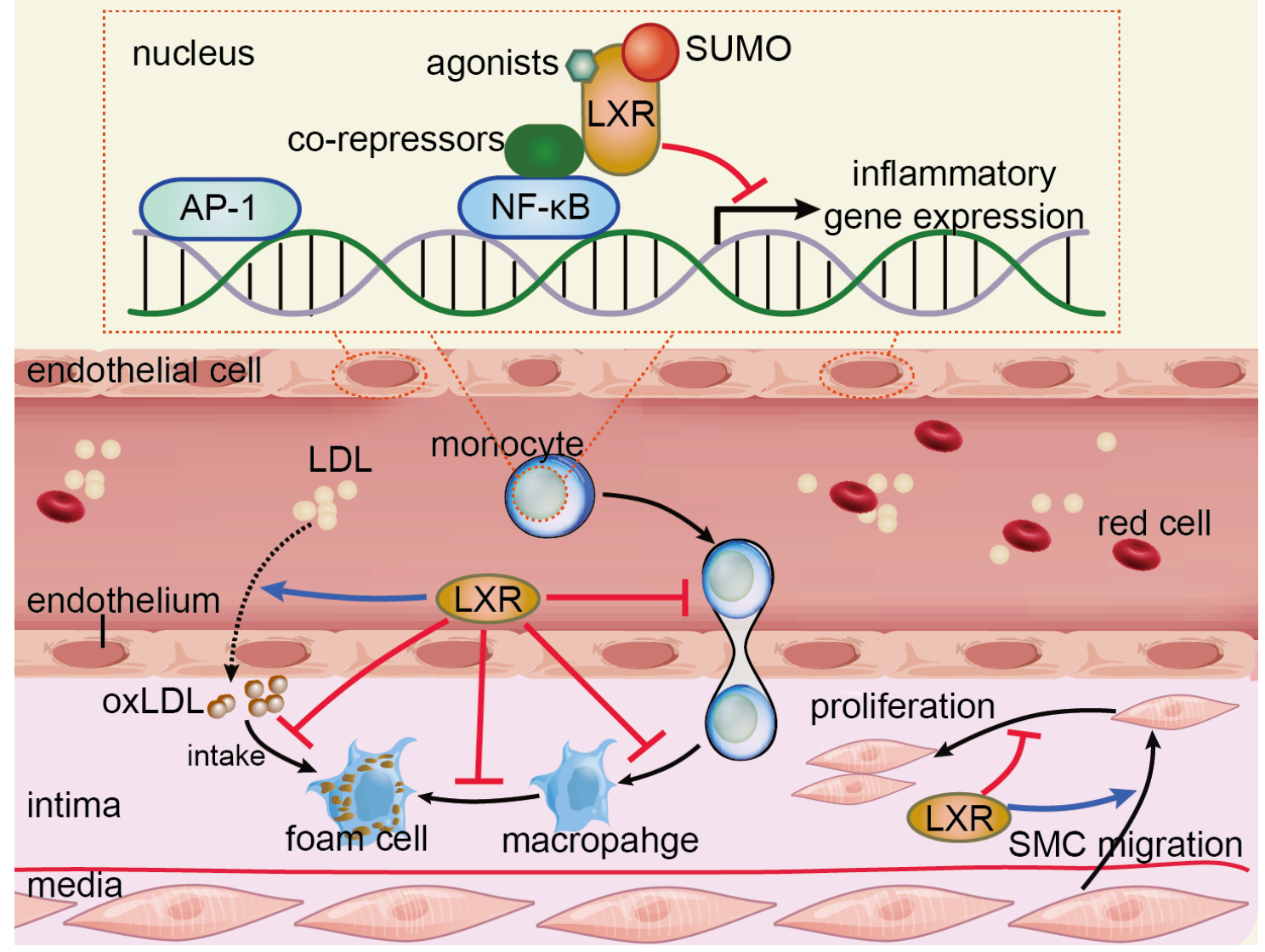

Figure 3. Molecular mechanisms of LXR transrepression and anti-inflammatory actions of LXRs in atherosclerosis. Inflammatory gene promoters are most often associated with the binding sites for NF-kB or AP-1 transcription factors. SUMOylated LXR is recruited to a proinflammatory gene promoter, where it binds and stabilizes the transrepression complex, thereby repressing pro-inflammatory signaling in macrophages and endothelial cells. Moreover, LXR activation increases macrophage cholesterol efflux and decreases macrophage infiltration and SMC proliferation. The roles of LXRs in macrophages and SMCs are highlighted with blue arrows. Abbreviations: NF-kB, nuclear factor $\mathrm{KB}$; AP-1, activator protein 1; SMC, smooth muscle cell.

proteinase-9 (MMP-9), in a repressed state (Ghisletti et al., 2007; Im and Osborne, 2011; Khan et al., 2016) (Figure 3). Recent work by Kappus et al. showed that LXR activation by T0901317 decreased inflammatory gene expression in vitro in lipopolysaccharide (LPS)stimulated macrophages that lacked ABCA1 and ABCG1. These inflammatory genes included

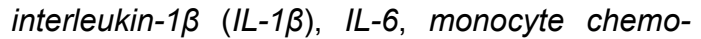
attractant protein $1(M c p-1)$ and macrophage inflammatory protein $1 \alpha($ Mip-1 $\alpha)$. Moreover, LXR activation decreased atherosclerosis and macrophage infiltration in $L d l r^{/-}$mice that received transplanted Abca1\% Abcg $1^{-/}$bone marrow (Kappus et al., 2014). These findings suggest that selective LXR agonists that mediate inflammatory transrepression without directly targeting cholesterol efflux, IDOL or lipogenic genes should be further developed as antiatherosclerosis therapeutic methods.

\section{Endothelial cells and smooth muscle cells}

In contrast with the well-studied role of LXR signaling in macrophages, the impact of LXR activity on other cells that directly affect atherosclerosis, including endothelial cells and smooth muscle cells (SMCs), has been investigated to a lesser extent. Blaschke et al. have demonstrated that both LXR $\alpha$ and LXR $\beta$ are expressed in human coronary artery SMCs and that the activation of LXRs by T0901317 and GW3965 inhibits SMC proliferation and neointima formation after balloon injury (Blaschke et al., 2004). Moreover, 4-1/2 LIM protein 2 (FHL2), interacting with and regulating several transcription factors, is not only involved in the phenotypic modulation of SMCs but also 
inhibits SMC proliferation and migration. A recent study by Kurakula et al. showed that FHL2 is a co-activator of LXRs in SMCs and enhances ApoA1- and HDL-mediated cholesterol efflux via regulating $\mathrm{ABCA} 1$ expression at the transcriptional level (Kurakula et al., 2015). Thus, those studies suggest that LXR activation may exert atheroprotective roles in SMCs.

Vascular endothelial dysfunction occurs during the early onset of atherogenesis, and inflammation is an important trigger of endothelial dysfunction. Endothelin-1 (ET-1), which is primarily produced by vascular endothelial cells, plays an important role in the pathogenesis of inflammatory diseases. Gao et al. reported that the activation of LXRs significantly attenuates LPS-induced ET-1 expression by inhibiting AP-1 or NF-kB signaling via transrepression (Gao et al., 2012). Spillmann and colleagues reported that LXR agonists (T0901317 and GW3965) directly improve TNFa-induced endothelial dysfunction by their anti-apoptotic, anti-inflammatory, and antioxidative properties and their capacity to restore NO bioavailability, independent of their cholesterol-modulating effects (Spillmann et al., 2014). Although the roles of LXRs in endothelial cells and SMCs are less understood, these results suggest that LXRs exert an antiatherosclerotic effect in these cells, and these findings warrant further investigation.

\section{Role of LXRs against myocardial diseases \\ Myocardial ischemia/reperfusion injury}

Previous studies have demonstrated that both $L X R \alpha$ and $L X R \beta$ are expressed in the cardiovascular system, where they may play significant roles in protecting against myocardial ischemia/reperfusion (MI/R) injury (Lei et al., 2013). Recent work by Wang et al. demonstrated that T0901317 enhances the functional survival of transplanted adipose-derived mesenchymal stem cells (AD-MSCs) in infarcted myocardium via the modulation of the Toll-like receptor 4/ myeloid differentiation factor $88 / \mathrm{NF}-\mathrm{KB}$ and Kelch-like $\mathrm{ECH}$-associated protein 1/Nrf2/heme oxygenase-1 signaling pathways. Moreover, a combined therapy consisting of an LXR agonist and AD-MSCs had a synergetic effect on cardiac repair and functional improvement after infarction (Wang et al., 2014). Using an MI/R model of LXR-deficient (LXRa knockout, LXR knockout or $L X R \alpha / \beta$ double-knockout) and LXRoverexpressing male mice, $\mathrm{He}$ et al. reported that $L X R \alpha$, but not $L X R \beta$, is significantly upregulated after MI/R. Moreover, the activation of LXR $\alpha$ instead of $L X R \beta$ plays a cardioprotective role in $M I / R$ injury by reducing endoplasmic reticulum stress- and mitochondrialmediated apoptosis. Mechanistically, LXR activation significantly decreases myocardial NADPH oxidase expression, attenuates superoxide generation, and reduces iNOS and tissue nitrotyrosine content in myocardium after ischemia/reperfusion ( $\mathrm{He}$ et al., 2014a). In addition, several members of the nuclear hormone receptor superfamily, such as PPARs, estrogen receptors and androgen receptors, have been proposed as the endogenous protective receptors that act against myocardial apoptosis and MI/R injury, while the activation of the farnesoid $X$ receptor and Nur77 exacerbates myocardial apoptosis and MI/R injury (Lin et al., 2009; Pu et al., 2013; Tsang et al., 2008). Therefore, it is conceivable that potential regulatory cross-talk among LXRa and these nuclear factors may maintain a delicate homeostatic balance between cellular death and survival in the heart.

\section{Diabetic cardiomyopathy}

Diabetic cardiomyopathy (DCM) is defined as diabetes-induced pathologic abnormalities and includes myocardial metabolic disturbances, oxidative/nitrative stress, inflammation, cardiomyocyte apoptosis, left ventricular dysfunction and structural remodeling (Huynh et al., 2014). Several studies have suggested that LXR $\alpha$ may be involved in cardioprotection against DCM (Cheng et al., 2011; He et al., 2014b; Huynh et al., 2014). Recent work by $\mathrm{He}$ et al. demonstrated that $L X R \alpha$, instead of $L X R \beta$, is selectively upregulated by hyperglycemia in male diabetic mice (He et al., 2014b). Moreover, GW3965 exerts a cardioprotective effect against DCM by attenuating insulin resistance, restoring Akt phosphorylation, inhibiting mitogen-activated protein kinase (MAPK) phosphorylation, reducing oxidative/nitrative stress and suppressing NF-KB activation and inflammation (He et al., 2014b). Therefore, LXR is a potentially attractive molecular target for the treatment of DCM. In addition, further studies are warranted to define whether the activation of $L X R \alpha, L X R \beta$, or both is involved in myocardial protection against DCM and to better define the complex mechanisms involving LXR during the regulation of oxidative stress and inflammatory responses. 
Myocardial hypertrophy

Myocardial hypertrophy is a major risk factor for the development of heart failure. It occurs in response to a wide range of pathological stimuli, such as arterial hypertension, valvular heart disease, myocardial infarction, inflammation and sarcomeric dysfunction by compensatory growth (Lorell and Carabello, 2000). LXR activation by T0901317 plays a cardioprotective role in attenuating myocardial hypertrophy in vivo (Kuipers et al., 2010a). LXR a activation suppresses the renin-angiotensin-aldosterone system (RAAS) by reducing the renin, angiotensin II type 1 receptor (AT1R) and angiotensin converting enzyme (ACE) expression in the heart and kidneys (Kuipers et al., 2010b). Moreover, Wu et al. reported that $L X R \alpha$ is upregulated in hypertrophic hearts induced to undergo left ventricular pressure overload, and the administration of T0901317 suppresses angiotensin II- and LPS-induced cardiomyocyte hypertrophy by inhibiting NF-kB signaling in mice. Both $L X R \alpha$ and $L X R \beta$ may inhibit NF-KB signaling, whereas LXRa may be more responsive to hypertrophic stimuli (Wu et al., 2009). Recent work by Cannon et al. demonstrated that LXR activation by AZ876 significantly reduces transverse aortic constriction-induced increases in heart weight, myocardial fibrosis, and cardiac dysfunction without affecting blood pressure. Mechanistically, AZ876 suppresses the upregulation of hypertrophy- and fibrosis-related genes and further inhibits pro-hypertrophic and pro-fibrotic transforming growth factor $\beta$ (TGF $\beta$ )-Smad2/3 signaling (Cannon et al., 2015). Accordingly, LXRs represent a potential molecular target for anti-hypertrophic and anti-fibrotic therapies, and more selective LXR agonists should be further explored for their cardioprotective potential.

\section{Future perspectives and conclusions}

Thus far, emerging LXR agonists have been shown to be potential therapeutic targets for many diseases; however, the clinical translation of novel, safe and effective synthetic LXR agonists has become the biggest obstacle to overcome in the future. As characterized by the treatment for atherosclerosis or dyslipidemia, LXR-623, CS8080, BMS-779788 and BMS852927, entered Phase 1 clinical trials and exhibited limited success but were terminated due to their unexpected or undisclosed adverse effects (Katz et al., 2009; Li et al., 2010; Loren et al., 2013) (Table 1). Unfortunately, there are still no clinically available synthetic LXR agonists. The discovery of $L X R \alpha / \beta$ partial agonists, such as LXR-623 and AZ876, is exciting (Katz et al., 2009; van der Hoorn et al., 2011). A balance between efficacy and several side effects, including hepatic lipogenesis, increases in TG, VLDL, CETP and IDOL levels, could be achieved with compounds that have partial activity for LXRa. However, the discovery of truly selective $L X R \beta$ agonists and safe LXR agonists requires further investigation.

Instead of atherosclerosis, synthetic LXR agonists play a protective role against several cardiovascular diseases. Using mice with multiple genetic alterations related to LXRs suggested that activation of $L X R a$, instead of $L X R \beta$, participates in cardioprotection against $M I / R$ injury and DCM development via its inhibitory roles on apoptosis, oxidative stress, and inflammation (He et al., 2014a; Huynh et al., 2014). However, there are some differences between humans and rodents in the LXR gene expression profile. Using other animal models, such as non-human primates and transgenic mice, which have LXR gene expression profiles more similar to that of humans (Honzumi et al., 2010), could provide more convincing evidence that LXRs are cardioprotective molecules. Moreover, such studies provide a theoretical basis for developing $L X R \alpha / \beta$ partial agonists to treat cardiovascular diseases.

Notably, several recent findings have indicated potential directions for future studies of treatments for atherosclerosis. MicroRNAs (miRNAs) modulate gene expression posttranscriptionally via base-pairing to target mRNAs, and they regulate a wide range of cellular processes (Ambros, 2004). Emerging evidence has suggested that several miRNAs participate in the regulation of the lipid metabolism. Recent work by Liu et al. showed that the translational activation of $L X R \alpha$ by miR-28-5p is involved in miR-28-5p-mediated ABCA1 upregulation in HepG2 cells and THP-1derived macrophages, which may contribute to cardioprotection against atherosclerosis (Traini et al., 2014). Moreover, Ramírez and colleagues demonstrated that T0901317 increases miR-144 expression in macrophages and mouse livers. The overexpression of miR-144 reduces ABCA1 expression, while the silencing of miR-144 in mice increases the expression of $A B C A 1$ and plasma HDL levels (Ramirez et al., 2013). Thus, 


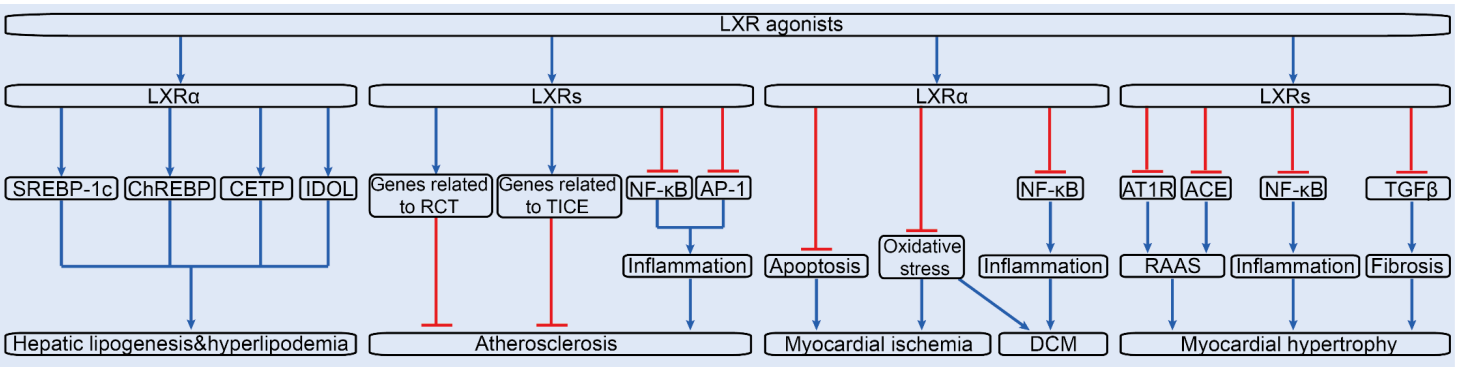

Figure 4. Mechanisms of the cardioprotection mediated by the LXRs signaling network. SREBP-1c, sterol regulatory element-binding protein-1c gene; ChREBP, carbohydrate response element-binding protein; CETP, cholesteryl ester transfer protein; IDOL, inducible degrader of the LDL receptor; NF-kB, nuclear factor KB; AP-1, activator protein 1; TICE, trans-intestinal cholesterol efflux; RCT, reverse cholesterol transport; DCM, diabetic cardiomyopathy; AT1R, angiotensin II type 1 receptor; ACE, angiotensin converting enzyme; RAAS, renin-angiotensin-aldosterone system; TGF $\beta$, transforming growth factor $\beta$.

the modulation of miRNAs may represent a potential therapeutic approach for treating dyslipidemia and atherosclerotic vascular disease. In addition, other miRNAs, including miR-33 (Rayner et al., 2011), miR-785 (Ramirez et al., 2011), miR-106b and miR-26 (Kim et al., 2012; Sun et al., 2012), have also been shown to regulate the expression of $A B C A 1$, and whether there are interactions between LXRs and these miRNAs remains to be determined.

In 2015, Zhang and colleagues demonstrated that nanoparticles (NPs) containing GW3965 (NP-LXR) inhibit the development of atherosclerosis without causing hepatic steatosis (Zhang et al., 2015). The engineered NPs are self-assembled in a biodegradable diblock poly(lactide-co-glycolide)- $b$-poly(ethylene glycol) (PLGA-b-PEG) copolymer (Swami et al., 2014). PLGA- $b$-PEG copolymers are biocompatible, biodegradable, and used in many products that are already approved by the US Food and Drug Administration (FDA). Moreover, NP-LXR is significantly more effective than free GW3965 at inducing LXR-targeted gene expression and suppressing inflammatory factors in macrophages in vitro and in vivo. In addition, the NPs elicit negligible levels of lipogenic gene stimulation in the liver (Zhang et al., 2015). Therefore, NPs encapsulating LXR agonists may be a promising nano-therapeutic approach for combating atherosclerosis without side effects.

We propose a model of the probable processes involved in LXR-related protection against several cardiovascular diseases by connecting all of the effectors and pathways described above. LXR agonists, such as oxysterols, synthetic LXR agonists, and non-classic LXR agonists, regulate the expression and function of LXRs. Furthermore, the activation of LXRs plays a cardioprotective role in promoting RCT and TICE, suppressing inflammation, and decreasing oxidation and apoptosis, as well as suppressing insulin resistance and hypertrophy. Taken together, these activities may constitute an interactive network that protects the heart against atherosclerosis, MI/R injury, DCM or myocardial hypertrophy. In this network, we may find that distinct pathways intersect, and these intersections may suggest new targets for exploring cardioprotection (Figure 4).

In summary, increasing evidence produced by basic research suggests that the activation of LXRs protects the heart from several cardiovascular diseases. Numerous regulators and signaling targets of LXRs have provided researchers with many opportunities to explore their underlying mechanisms. With the in-depth understanding of LXR biology and the development of innovative drug discovery strategies, several LXR isotype-selective agonists have emerged and even entered clinical trials. Unfortunately, no compounds have yet been approved by the US FDA for clinical treatment due to several unexpected side effects, such as adverse CNS events. However, it is undeniable that LXRs are important therapeutic targets for cardiovascular diseases and maintaining cholesterol homeostasis. Thus, the advancement of drug discovery programs could promote the development of safe and 
effective LXR agonists for future clinical applications.

\section{Disclosure}

The authors declare no competing interests.

\section{Acknowledgements}

This work was supported by National Natural Science Foundation of China (81500263), the China Postdoctoral Science Foundation (2015M572681), and the Excellent Doctoral Support Project of the Fourth Military Medical University (2015D02).

\section{References}

Allen, A.M., Taylor, J.M., and Graham, A. (2013). Mitochondrial (dys)function and regulation of macrophage cholesterol efflux. Clinical science (London, England : 1979) 124, 509-515.

Altmann, S.W., Davis, H.R., Jr., Zhu, L.J., Yao, X., Hoos, L.M., Tetzloff, G., Iyer, S.P., Maguire, M., Golovko, A., Zeng, M., et al. (2004). Niemann-Pick C1 Like 1 protein is critical for intestinal cholesterol absorption. Science (New York, NY) 303, 1201-1204.

Ambros, V. (2004). The functions of animal microRNAs. Nature 431, 350-355.

Angelone, T., Filice, E., Quintieri, A.M., Imbrogno, S., Recchia, A., Pulera, E., Mannarino, C., Pellegrino, D., and Cerra, M.C. (2008). Beta3-adrenoceptors modulate left ventricular relaxation in the rat heart via the NO-cGMP-PKG pathway. Acta physiologica (Oxford, England) 193, 229-239.

Apfel, R., Benbrook, D., Lernhardt, E., Ortiz, M.A., Salbert, G., and Pfahl, M. (1994). A novel orphan receptor specific for a subset of thyroid hormone-responsive elements and its interaction with the retinoid/thyroid hormone receptor subfamily. Molecular and cellular biology 14, 7025-7035.

Aye, I.L., Waddell, B.J., Mark, P.J., and Keelan, J.A. (2010). Placental ABCA1 and ABCG1 transporters efflux cholesterol and protect trophoblasts from oxysterol induced toxicity. Biochimica et biophysica acta 1801, 1013-1024.

Baldan, A., Pei, L., Lee, R., Tarr, P., Tangirala, R.K., Weinstein, M.M., Frank, J., Li, A.C., Tontonoz, P., and Edwards, P.A. (2006). Impaired development of atherosclerosis in hyperlipidemic Ldlr-/- and ApoE-/- mice transplanted with Abcg1-/- bone marrow. Arteriosclerosis, thrombosis, and vascular biology 26, 2301-2307.
Barter, P.J., Brewer, H.B., Jr., Chapman, M.J., Hennekens, C.H., Rader, D.J., and Tall, A.R. (2003). Cholesteryl ester transfer protein: a novel target for raising $\mathrm{HDL}$ and inhibiting atherosclerosis. Arteriosclerosis, thrombosis, and vascular biology $23,160-167$.

Beltowski, J. (2008). Liver X receptors (LXR) as therapeutic targets in dyslipidemia. Cardiovascular therapeutics 26, 297-316.

Berge, K.E., Tian, H., Graf, G.A., Yu, L., Grishin, N.V., Schultz, J., Kwiterovich, P., Shan, B., Barnes, R., and Hobbs, H.H. (2000). Accumulation of dietary cholesterol in sitosterolemia caused by mutations in adjacent ABC transporters. Science (New York, NY) 290, 1771-1775.

Beyea, M.M., Reaume, S., Sawyez, C.G., Edwards, J.Y., O'Neil, C., Hegele, R.A., Pickering, J.G., and Huff, M.W. (2012). The oxysterol 24(s),25-epoxycholesterol attenuates human smooth muscle-derived foam cell formation via reduced low-density lipoprotein uptake and enhanced cholesterol efflux. Journal of the American Heart Association 1, e000810.

Blaschke, F., Leppanen, O., Takata, Y., Caglayan, E., Liu, J., Fishbein, M.C., Kappert, K., Nakayama, K.I., Collins, A.R., Fleck, E., et al. (2004). Liver $X$ receptor agonists suppress vascular smooth muscle cell proliferation and inhibit neointima formation in balloon-injured rat carotid arteries. Circulation research 95, e110-123.

Bodzioch, M., Orso, E., Klucken, J., Langmann, T., Bottcher, A., Diederich, W., Drobnik, W., Barlage, S., Buchler, C., Porsch-Ozcurumez, M., et al. (1999). The gene encoding ATPbinding cassette transporter 1 is mutated in Tangier disease. Nature genetics 22, 347-351.

Bonamassa, B., and Moschetta, A. (2013). Atherosclerosis: lessons from LXR and the intestine. Trends in endocrinology and metabolism: TEM 24, 120-128.

Boyle, J.J., Harrington, H.A., Piper, E., Elderfield, K., Stark, J., Landis, R.C., and Haskard, D.O. (2009). Coronary intraplaque hemorrhage evokes a novel atheroprotective macrophage phenotype. The American journal of pathology 174, 1097-1108.

Brown, M.L., Inazu, A., Hesler, C.B., Agellon, L.B., Mann, C., Whitlock, M.E., Marcel, Y.L., Milne, R.W., Koizumi, J., Mabuchi, H., et al. (1989). Molecular basis of lipid transfer protein deficiency in a family with increased highdensity lipoproteins. Nature 342, 448-451. 
Brufau, G., Groen, A.K., and Kuipers, F. (2011). Reverse cholesterol transport revisited: contribution of biliary versus intestinal cholesterol excretion. Arteriosclerosis, thrombosis, and vascular biology 31 , 1726-1733.

Brunham, L.R., Kruit, J.K., Iqbal, J., Fievet, C., Timmins, J.M., Pape, T.D., Coburn, B.A., Bissada, N., Staels, B., Groen, A.K., et al. (2006). Intestinal ABCA1 directly contributes to HDL biogenesis in vivo. The Journal of clinical investigation 116, 1052-1062.

Brunham, L.R., Singaraja, R.R., Duong, M., Timmins, J.M., Fievet, C., Bissada, N., Kang, M.H., Samra, A., Fruchart, J.C., McManus, B., et al. (2009). Tissue-specific roles of ABCA1 influence susceptibility to atherosclerosis. Arteriosclerosis, thrombosis, and vascular biology 29, 548-554.

Buono, C., Li, Y., Waldo, S.W., and Kruth, H.S. (2007). Liver $X$ receptors inhibit human monocyte-derived macrophage foam cell formation by inhibiting fluid-phase pinocytosis of LDL. Journal of lipid research 48, 2411-2418.

Byun, H.W., Hong, E.M., Park, S.H., Koh, D.H., Choi, M.H., Jang, H.J., Kae, S.H., and Lee, J. (2014). Pravastatin activates the expression of farnesoid $X$ receptor and liver $X$ receptor alpha in Hep3B cells. Hepatobiliary and pancreatic diseases international : HBPD INT 13, 65-73.

Calkin, A.C., and Tontonoz, P. (2010). Liver x receptor signaling pathways and atherosclerosis. Arteriosclerosis, thrombosis, and vascular biology 30, 1513-1518.

Campia, I., Sala, V., Kopecka, J., Leo, C., Mitro, N., Costamagna, C., Caruso, D., Pescarmona, G., Crepaldi, T., Ghigo, D., et al. (2012). Digoxin and ouabain induce the efflux of cholesterol via liver $X$ receptor signalling and the synthesis of ATP in cardiomyocytes. The Biochemical journal 447, 301-311.

Cannon, M.V., Yu, H., Candido, W.M., Dokter, M.M., Lindstedt, E.L., Sillje, H.H., van Gilst, W.H., and de Boer, R.A. (2015). The liver X receptor agonist AZ876 protects against pathological cardiac hypertrophy and fibrosis without lipogenic side effects. European journal of heart failure 17, 273-282.

Cheng, Y., Liu, G., Pan, Q., Guo, S., and Yang, X. (2011). Elevated expression of liver $X$ receptor alpha (LXRalpha) in myocardium of streptozotocin-induced diabetic rats. Inflammation 34, 698-706.
Chung, S., Sawyer, J.K., Gebre, A.K., Maeda, N., and Parks, J.S. (2011). Adipose tissue ATP binding cassette transporter $\mathrm{A} 1$ contributes to high-density lipoprotein biogenesis in vivo. Circulation 124, 1663-1672.

Collins, J.L., Fivush, A.M., Watson, M.A., Galardi, C.M., Lewis, M.C., Moore, L.B., Parks, D.J., Wilson, J.G., Tippin, T.K., Binz, J.G., et al. (2002). Identification of a nonsteroidal liver $X$ receptor agonist through parallel array synthesis of tertiary amines. Journal of medicinal chemistry 45, 1963-1966.

Costet, P., Luo, Y., Wang, N., and Tall, A.R. (2000). Sterol-dependent transactivation of the $A B C 1$ promoter by the liver $X$ receptor/retinoid $X$ receptor. The Journal of biological chemistry 275, 28240-28245.

Dullaart, R.P., Dallinga-Thie, G.M., Wolffenbuttel, B.H., and van Tol, A. (2007). CETP inhibition in cardiovascular risk management: a critical appraisal. European journal of clinical investigation $37,90-98$.

El Messaoudi, S., Rongen, G.A., de Boer, R.A., and Riksen, N.P. (2011). The cardioprotective effects of metformin. Current opinion in lipidology 22, 445-453.

Faulds, M.H., Zhao, C., and Dahlman-Wright, K. (2010). Molecular biology and functional genomics of liver $X$ receptors (LXR) in relationship to metabolic diseases. Current opinion in pharmacology 10, 692-697.

Francis, G.A. (2010). The complexity of HDL. Biochimica et biophysica acta 1801 , 1286-1293.

Fu, X., Menke, J.G., Chen, Y., Zhou, G., MacNaul, K.L., Wright, S.D., Sparrow, C.P., and Lund, E.G. (2001). 27-hydroxycholesterol is an endogenous ligand for liver $\mathrm{X}$ receptor in cholesterol-loaded cells. The Journal of biological chemistry 276, 38378-38387.

Gao, M., Zeng, Y., Guan, Y., Hu, Z., Zhong, D., Shen, X., Zhang, L., Xu, Z., Gong, W., Zhang, $Y$., et al. (2012). Activation of liver $X$ receptor attenuates endothelin-1 expression in vascular endothelial cells. The international journal of biochemistry and cell biology 44, 2299-2307.

Ghisletti, S., Huang, W., Ogawa, S., Pascual, G., Lin, M.E., Willson, T.M., Rosenfeld, M.G., and Glass, C.K. (2007). Parallel SUMOylationdependent pathways mediate gene- and signal-specific transrepression by LXRs and PPARgamma. Molecular cell 25, 57-70.

Ghosh, R.K., and Ghosh, S.M. (2012). Current status of CETP inhibitors in the treatment of 
hyperlipidemia: an update. Current clinical pharmacology $7,102-110$.

Giannarelli, C., Cimmino, G., Connolly, T.M., Ibanez, B., Ruiz, J.M., Alique, M., Zafar, M.U., Fuster, V., Feuerstein, G., and Badimon, J.J. (2012). Synergistic effect of liver $X$ receptor activation and simvastatin on plaque regression and stabilization: an magnetic resonance imaging study in a model of advanced atherosclerosis. European heart journal 33, 264-273.

Gonzalez-Granillo, M., Steffensen, K.R., Granados, O., Torres, N., Korach-Andre, M., Ortiz, V., Aguilar-Salinas, C., Jakobsson, T., Diaz-Villasenor, A., Loza-Valdes, A., et al. (2012). Soy protein isoflavones differentially regulate liver $\mathrm{X}$ receptor isoforms to modulate lipid metabolism and cholesterol transport in the liver and intestine in mice. Diabetologia 55, 2469-2478.

Goodwin, B., Watson, M.A., Kim, H., Miao, J., Kemper, J.K., and Kliewer, S.A. (2003). Differential regulation of rat and human CYP7A1 by the nuclear oxysterol receptor liver $X$ receptor-alpha. Molecular endocrinology (Baltimore, Md) 17, 386-394.

Gorenjak, M., Gradisnik, L., Trapecar, M., Pistello, M., Kozmus, C.P., Skorjanc, D., Skok, P., Langerholc, T., and Cencic, A. (2014). Improvement of lipid profile by probiotic/ protective cultures: study in a noncarcinogenic small intestinal cell model. The new microbiologica 37, 51-64.

Graf, G.A., Li, W.P., Gerard, R.D., Gelissen, I., White, A., Cohen, J.C., and Hobbs, H.H. (2002). Coexpression of ATP-binding cassette proteins ABCG5 and ABCG8 permits their transport to the apical surface. The Journal of clinical investigation 110, 659-669.

Gut, P., Baeza-Raja, B., Andersson, O., Hasenkamp, L., Hsiao, J., Hesselson, D., Akassoglou, K., Verdin, E., Hirschey, M.D., and Stainier, D.Y. (2013). Whole-organism screening for gluconeogenesis identifies activators of fasting metabolism. Nature chemical biology 9, 97-104.

Habegger, K.M., Stemmer, K., Cheng, C., Muller, T.D., Heppner, K.M., Ottaway, N., Holland, J., Hembree, J.L., Smiley, D., Gelfanov, V., et al. (2013). Fibroblast growth factor 21 mediates specific glucagon actions. Diabetes 62, 1453-1463.

Haghpassand, M., Bourassa, P.A., Francone, O.L., and Aiello, R.J. (2001). Monocyte/ macrophage expression of ABCA1 has minimal contribution to plasma HDL levels. The Journal of clinical investigation 108, 1315-1320.

Harasiuk, D., Baranowski, M., Zabielski, P., Chabowski, A., and Gorski, J. (2015). LXR agonist T0901317-Induced hyperlipidemia does not lead to lipid accumulation in the rat heart. Cellular physiology and biochemistry : international journal of experimental cellular physiology, biochemistry, and pharmacology 35, 1095-1106.

He, Q., Pu, J., Yuan, A., Lau, W.B., Gao, E., Koch, W.J., Ma, X.L., and He, B. (2014a). Activation of liver-X-receptor alpha but not liver-X-receptor beta protects against myocardial ischemia/reperfusion injury. Circulation Heart failure 7, 1032-1041.

He, Q., Pu, J., Yuan, A., Yao, T., Ying, X., Zhao, Y., Xu, L., Tong, H., and He, B. (2014b). Liver $X$ receptor agonist treatment attenuates cardiac dysfunction in type 2 diabetic $\mathrm{db} / \mathrm{db}$ mice. Cardiovascular diabetology 13, 149.

Hirano, K., Yamashita, S., Nakagawa, Y., Ohya, T., Matsuura, F., Tsukamoto, K., Okamoto, Y., Matsuyama, A., Matsumoto, K., Miyagawa, J., et al. (1999). Expression of human scavenger receptor class B type I in cultured human monocyte-derived macrophages and atherosclerotic lesions. Circulation research 85, 108-116.

Hong, C., Marshall, S.M., McDaniel, A.L., Graham, M., Layne, J.D., Cai, L., Scotti, E., Boyadjian, R., Kim, J., Chamberlain, B.T., et al. (2014). The LXR-Idol axis differentially regulates plasma LDL levels in primates and mice. Cell metabolism 20, 910-918.

Hong, C., and Tontonoz, P. (2014). Liver X receptors in lipid metabolism: opportunities for drug discovery. Nature reviews Drug discovery 13, 433-444.

Honzumi, S., Shima, A., Hiroshima, A., Koieyama, T., Ubukata, N., and Terasaka, N. (2010). LXRalpha regulates human CETP expression in vitro and in transgenic mice. Atherosclerosis 212, 139-145.

$\mathrm{Hu}$, X., Li, S., Wu, J., Xia, C., and Lala, D.S. (2003). Liver $X$ receptors interact with corepressors to regulate gene expression. Molecular endocrinology (Baltimore, Md) 17, 1019-1026.

Huuskonen, J., Fielding, P.E., and Fielding, C.J. (2004). Role of p160 coactivator complex in the activation of liver $X$ receptor. Arteriosclerosis, thrombosis, and vascular biology 24, 703-708. 
Huwait, E.A., Greenow, K.R., Singh, N.N., and Ramji, D.P. (2011). A novel role for c-Jun Nterminal kinase and phosphoinositide 3-kinase in the liver $X$ receptor-mediated induction of macrophage gene expression. Cellular signalling 23, 542-549.

Huynh, K., Bernardo, B.C., McMullen, J.R., and Ritchie, R.H. (2014). Diabetic cardiomyopathy: mechanisms and new treatment strategies targeting antioxidant signaling pathways. Pharmacology and therapeutics 142, 375-415.

Ikegami, T., Hyogo, H., Honda, A., Miyazaki, T., Tokushige, K., Hashimoto, E., Inui, K., Matsuzaki, Y., and Tazuma, S. (2012). Increased serum liver $X$ receptor ligand oxysterols in patients with non-alcoholic fatty liver disease. Journal of gastroenterology 47 , 1257-1266.

$\mathrm{Im}$, S.S., and Osborne, T.F. (2011). Liver $\mathrm{x}$ receptors in atherosclerosis and inflammation. Circulation research 108, 996-1001.

Inazu, A., Jiang, X.C., Haraki, T., Yagi, K., Kamon, N., Koizumi, J., Mabuchi, H., Takeda, R., Takata, K., Moriyama, Y., et al. (1994). Genetic cholesteryl ester transfer protein deficiency caused by two prevalent mutations as a major determinant of increased levels of high density lipoprotein cholesterol. The Journal of clinical investigation 94, 1872-1882.

Iwanicki, T., Balcerzyk, A., Niemiec, P., Nowak, T., Ochalska-Tyka, A., Krauze, J., KosiorzGorczynska, S., Grzeszczak, W., and Zak, I. (2015). CYP7A1 gene polymorphism located in the $5^{\prime}$ upstream region modifies the risk of coronary artery disease. Disease markers 2015, 185969.

Jakobsson, T., Treuter, E., Gustafsson, J.A., and Steffensen, K.R. (2012). Liver $X$ receptor biology and pharmacology: new pathways, challenges and opportunities. Trends in pharmacological sciences 33, 394-404.

Janowski, B.A., Grogan, M.J., Jones, S.A., Wisely, G.B., Kliewer, S.A., Corey, E.J., and Mangelsdorf, D.J. (1999). Structural requirements of ligands for the oxysterol liver $X$ receptors LXRalpha and LXRbeta. Proceedings of the National Academy of Sciences of the United States of America 96, 266-271.

Janowski, B.A., Willy, P.J., Devi, T.R., Falck, J.R., and Mangelsdorf, D.J. (1996). An oxysterol signalling pathway mediated by the nuclear receptor LXR alpha. Nature 383, 728-731.

Joseph, S.B., Castrillo, A., Laffitte, B.A., Mangelsdorf, D.J., and Tontonoz, P. (2003).
Reciprocal regulation of inflammation and lipid metabolism by liver $X$ receptors. Nature medicine 9, 213-219.

Joseph, S.B., McKilligin, E., Pei, L., Watson, M.A., Collins, A.R., Laffitte, B.A., Chen, M., Noh, G., Goodman, J., Hagger, G.N., et al. (2002). Synthetic LXR ligand inhibits the development of atherosclerosis in mice. Proceedings of the National Academy of Sciences of the United States of America 99, 7604-7609.

Kappus, M.S., Murphy, A.J., Abramowicz, S., Ntonga, V., Welch, C.L., Tall, A.R., and Westerterp, M. (2014). Activation of liver $X$ receptor decreases atherosclerosis in $\operatorname{Ldlr}(-) /$ $(-)$ mice in the absence of ATP-binding cassette transporters $A 1$ and $\mathrm{G} 1$ in myeloid cells. Arteriosclerosis, thrombosis, and vascular biology 34, 279-284.

Katz, A., Udata, C., Ott, E., Hickey, L., Burczynski, M.E., Burghart, P., Vesterqvist, O., a nd Meng, X. ( 2009$)$. S a fety, pharmacokinetics, and pharmacodynamics of single doses of LXR-623, a novel liver Xreceptor agonist, in healthy participants. Journal of clinical pharmacology 49, 643-649.

Kennedy, M.A., Barrera, G.C., Nakamura, K., Baldan, A., Tarr, P., Fishbein, M.C., Frank, J., Francone, O.L., and Edwards, P.A. (2005). ABCG1 has a critical role in mediating cholesterol efflux to HDL and preventing cellular lipid accumulation. Cell metabolism 1, 121-131.

Khan, F.A., Pandupuspitasari, N.S., Huang, C.J., Hao, X., and Zhang, S. (2016). SUMOylation: A link to future therapeutics. Current issues in molecular biology 18, 49-56.

Khera, A.V., and Rader, D.J. (2010). Future therapeutic directions in reverse cholesterol transport. Current atherosclerosis reports 12, 73-81.

Kim, G.H., Park, K., Yeom, S.Y., Lee, K.J., Kim, G., Ko, J., Rhee, D.K., Kim, Y.H., Lee, H.K., Kim, H.W., et al. (2009). Characterization of ASC-2 as an antiatherogenic transcriptional coactivator of liver $X$ receptors in macrophages. Molecular endocrinology (Baltimore, Md) 23, 966-974.

Kim, J., Yoon, H., Ramirez, C.M., Lee, S.M., Hoe, H.S., Fernandez-Hernando, C., and Kim, J. (2012). MiR-106b impairs cholesterol efflux and increases Abeta levels by repressing ABCA1 expression. Experimental neurology 235, 476-483. 
Kingwell, B.A., Chapman, M.J., Kontush, A., and Miller, N.E. (2014). HDL-targeted therapies: progress, failures and future. Nature reviews Drug discovery 13, 445-464.

Koschack, J., Lutjohann, D., Schmidt-Samoa, C., and Irle, E. (2009). Serum 24Shydroxycholesterol and hippocampal size in middle-aged normal individuals. Neurobiology of aging 30, 898-902.

Kuipers, I., Li, J., Vreeswijk-Baudoin, I., Koster, J., van der Harst, P., Sillje, H.H., Kuipers, F., van Veldhuisen, D.J., van Gilst, W.H., and de Boer, R.A. (2010a). Activation of liver $X$ receptors with T0901317 attenuates cardiac hypertrophy in vivo. European journal of heart failure 12, 1042-1050.

Kuipers, I., van der Harst, P., Kuipers, F., van Genne, L., Goris, M., Lehtonen, J.Y., van Veldhuisen, D.J., van Gilst, W.H., and de Boer, R.A. (2010b). Activation of liver $X$ receptoralpha reduces activation of the renal and cardiac renin-angiotensin-aldosterone system. Laboratory investigation; a journal of technical methods and pathology 90,630-636.

Kurakula, K., Sommer, D., Sokolovic, M., Moerland, P.D., Scheij, S., van Loenen, P.B., Koenis, D.S., Zelcer, N., van Tiel, C.M., and de Vries, C.J. (2015). LIM-only protein FHL2 is a positive regulator of liver $X$ receptors in smooth muscle cells involved in lipid homeostasis. Molecular and cellular biology $35,52-62$.

Laffitte, B.A., Repa, J.J., Joseph, S.B., Wilpitz, D.C., Kast, H.R., Mangelsdorf, D.J., and Tontonoz, P. (2001). LXRs control lipidinducible expression of the apolipoprotein $\mathrm{E}$ gene in macrophages and adipocytes. Proceedings of the National Academy of Sciences of the United States of America 98, 507-512.

Lammers, B., Out, R., Hildebrand, R.B., Quinn, C.M., Williamson, D., Hoekstra, M., Meurs, I., Van Berkel, T.J., Jessup, W., and Van Eck, M. (2009). Independent protective roles for macrophage Abcg1 and Apoe in the atherosclerotic lesion development. Atherosclerosis 205, 420-426.

Lei, P., Baysa, A., Nebb, H.I., Valen, G., Skomedal, T., Osnes, J.B., Yang, Z., and Haugen, F. (2013). Activation of Liver X receptors in the heart leads to accumulation of intracellular lipids and attenuation of ischemiareperfusion injury. Basic research in cardiology $108,323$.
Li, X., Yeh, V., and Molteni, V. (2010). Liver X receptor modulators: a review of recently patented compounds (2007 - 2009). Expert opinion on therapeutic patents 20,535-562.

Li, Y.H., and Liu, L. (2014). Apolipoprotein E synthesized by adipocyte and apolipoprotein $\mathrm{E}$ carried on lipoproteins modulate adipocyte triglyceride content. Lipids in health and disease 13, 136.

Lin, J., Steenbergen, C., Murphy, E., and Sun, J. (2009). Estrogen receptor-beta activation results in S-nitrosylation of proteins involved in cardioprotection. Circulation 120, 245-254.

Lin, X.L., He, X.L., Zeng, J.F., Zhang, H., Zhao, Y., Tan, J.K., and Wang, Z. (2014). FGF21 increases cholesterol efflux by upregulating ABCA1 through the ERK1/2-PPARgammaLXRalpha pathway in THP1 macrophagederived foam cells. DNA and cell biology 33, 514-521.

Lorell, B.H., and Carabello, B.A. (2000). Left ventricular hypertrophy: pathogenesis, detection, and prognosis. Circulation 102, 470-479.

Loren, J., Huang, Z., Laffitte, B.A., and Molteni, V. (2013). Liver $X$ receptor modulators: a review of recently patented compounds (2009 - 2012). Expert opinion on therapeutic patents 23, 1317-1335.

Mahley, R.W., and Rall, S.C., Jr. (2000). Apolipoprotein E: far more than a lipid transport protein. Annual review of genomics and human genetics 1, 507-537.

Malerod, L., Juvet, L.K., Hanssen-Bauer, A., Eskild, W., and Berg, T. (2002). Oxysterolactivated LXRalpha/RXR induces hSR-BIpromoter activity in hepatoma cells and preadipocytes. Biochemical and biophysical research communications 299, 916-923.

Marshall, S.M., Kelley, K.L., Davis, M.A., Wilson, M.D., McDaniel, A.L., Lee, R.G., Crooke, R.M., Graham, M.J., Rudel, L.L., Brown, J.M., et al. (2014). Reduction of VLDL secretion decreases cholesterol excretion in niemannpick C1-like 1 hepatic transgenic mice. PloS one 9 , e84418.

Naik, S.U., Wang, X., Da Silva, J.S., Jaye, M., Macphee, C.H., Reilly, M.P., Billheimer, J.T., Rothblat, G.H., and Rader, D.J. (2006). Pharmacological activation of liver $X$ receptors promotes reverse cholesterol transport in vivo. Circulation 113, 90-97.

Noshiro, M., and Okuda, K. (1990). Molecular cloning and sequence analysis of cDNA 
encoding human cholesterol 7 alphahydroxylase. FEBS letters 268, 137-140.

Oram, J.F., and Heinecke, J.W. (2005). ATPbinding cassette transporter A1: a cell cholesterol exporter that protects against cardiovascular disease. Physiological reviews 85, 1343-1372.

Out, R., Hoekstra, M., Habets, K., Meurs, I., de Waard, V., Hildebrand, R.B., Wang, Y., Chimini, G., Kuiper, J., Van Berkel, T.J., et al. (2008). Combined deletion of macrophage $A B C A 1$ and $A B C G 1$ leads to massive lipid accumulation in tissue macrophages and distinct atherosclerosis at relatively low plasma cholesterol levels. Arteriosclerosis, thrombosis, and vascular biology $28,258-264$.

Out, R., Hoekstra, M., Hildebrand, R.B., Kruit, J.K., Meurs, I., Li, Z., Kuipers, F., Van Berkel, T.J., and Van Eck, M. (2006). Macrophage ABCG1 deletion disrupts lipid homeostasis in alveolar macrophages and moderately influences atherosclerotic lesion development in LDL receptor-deficient mice. Arteriosclerosis, thrombosis, and vascular biology 26 , 2295-2300.

Pannu, P.S., Allahverdian, S., and Francis, G.A. (2013). Oxysterol generation and liver $X$ receptor-dependent reverse cholesterol transport: not all roads lead to Rome. Molecular and cellular endocrinology 368, 99-107.

Peet, D.J., Janowski, B.A., and Mangelsdorf, D.J. (1998a). The LXRs: a new class of oxysterol receptors. Current opinion in genetics and development 8, 571-575.

Peet, D.J., Turley, S.D., Ma, W., Janowski, B.A., Lobaccaro, J.M., Hammer, R.E., and Mangelsdorf, D.J. (1998b). Cholesterol and bile acid metabolism are impaired in mice lacking the nuclear oxysterol receptor LXR alpha. Cell 93, 693-704.

$\mathrm{Pu}$, J., Yuan, A., Shan, P., Gao, E., Wang, X., Wang, Y., Lau, W.B., Koch, W., Ma, X.L., and $\mathrm{He}$, B. (2013). Cardiomyocyte-expressed farnesoid-X-receptor is a novel apoptosis mediator and contributes to myocardial ischaemia/reperfusion injury. European heart journal 34, 1834-1845.

Quack, M., Frank, C., and Carlberg, C. (2002). Differential nuclear receptor signalling from DR4-type response elements. Journal of cellular biochemistry $86,601-612$.

Quinet, E.M., Savio, D.A., Halpern, A.R., Chen, L., Miller, C.P., and Nambi, P. (2004). Geneselective modulation by a synthetic oxysterol ligand of the liver $X$ receptor. Journal of lipid research 45, 1929-1942.

Quintao, E.C. (2016). The controversy over the use of cholesteryl ester transfer protein inhibitors: is there some light at the end of the tunnel? European journal of clinical investigation 46, 581-589.

Ramirez, C.M., Davalos, A., Goedeke, L., Salerno, A.G., Warrier, N., Cirera-Salinas, D., Suarez, Y., and Fernandez-Hernando, C. (2011). MicroRNA-758 regulates cholesterol efflux through posttranscriptional repression of ATP-binding cassette transporter A1. Arteriosclerosis, thrombosis, and vascular biology 31, 2707-2714.

Ramirez, C.M., Rotllan, N., Vlassov, A.V., Davalos, A., Li, M., Goedeke, L., Aranda, J.F., Cirera-Salinas, D., Araldi, E., Salerno, A., et al. (2013). Control of cholesterol metabolism and plasma high-density lipoprotein levels by microRNA-144. Circulation research 112, 1592-1601.

Ranalletta, M., Wang, N., Han, S., Yvan-Charvet, L., Welch, C., and Tall, A.R. (2006). Decreased atherosclerosis in low-density lipoprotein receptor knockout mice transplanted with Abcg1-/- bone marrow. Arteriosclerosis, thrombosis, and vascular biology 26 , 2308-2315.

Rayner, K.J., Sheedy, F.J., Esau, C.C., Hussain, F.N., Temel, R.E., Parathath, S., van Gils, J.M., Rayner, A.J., Chang, A.N., Suarez, Y., et al. (2011). Antagonism of miR-33 in mice promotes reverse cholesterol transport and regression of atherosclerosis. The Journal of clinical investigation 121, 2921-2931.

Repa, J.J., Liang, G., Ou, J., Bashmakov, Y., Lobaccaro, J.M., Shimomura, I., Shan, B., Brown, M.S., Goldstein, J.L., and Mangelsdorf, D.J. (2000). Regulation of mouse sterol regulatory element-binding protein-1c gene (SREBP-1c) by oxysterol receptors, LXRalpha and LXRbeta. Genes and development 14, 2819-2830.

Rosenson, R.S., Brewer, H.B., Jr., Davidson, W.S., Fayad, Z.A., Fuster, V., Goldstein, J., Hellerstein, M., Jiang, X.C., Phillips, M.C., Rader, D.J., et al. (2012). Cholesterol efflux and atheroprotection: advancing the concept of reverse cholesterol transport. Circulation 125, 1905-1919.

Sanders, M.E. (2000). Considerations for use of probiotic bacteria to modulate human health. The Journal of nutrition 130, 384s-390s. 
Schultz, J.R., Tu, H., Luk, A., Repa, J.J., Medina, J.C., Li, L., Schwendner, S., Wang, S., Thoolen, M., Mangelsdorf, D.J., et al. (2000). Role of LXRs in control of lipogenesis. Genes and development 14, 2831-2838.

Schuster, G.U., Parini, P., Wang, L., Alberti, S., Steffensen, K.R., Hansson, G.K., Angelin, B., and Gustafsson, J.A. (2002). Accumulation of foam cells in liver $X$ receptor-deficient mice. Circulation 106, 1147-1153.

Spillmann, F., Van Linthout, S., Miteva, K., Lorenz, M., Stangl, V., Schultheiss, H.P., and Tschope, C. (2014). LXR agonism improves TNF-alpha-induced endothelial dysfunction in the absence of its cholesterol-modulating effects. Atherosclerosis 232, 1-9.

Steffensen, K.R., Jakobsson, T., and Gustafsson, J.A. (2013). Targeting liver X receptors in inflammation. Expert opinion on therapeutic targets 17, 977-990.

Stukas, S., May, S., Wilkinson, A., Chan, J., Donkin, J., and Wellington, C.L. (2012). The LXR agonist GW3965 increases apoA-I protein levels in the central nervous system independent of ABCA1. Biochimica et biophysica acta 1821, 536-546.

Sun, D., Zhang, J., Xie, J., Wei, W., Chen, M., and Zhao, X. (2012). MiR-26 controls LXRdependent cholesterol efflux by targeting ABCA1 and ARL7. FEBS letters 586, 1472-1479.

Svensson, S., Ostberg, T., Jacobsson, M., Norstrom, C., Stefansson, K., Hallen, D., Johansson, I.C., Zachrisson, K., Ogg, D., and Jendeberg, L. (2003). Crystal structure of the heterodimeric complex of LXRalpha and RXRbeta ligand-binding domains in a fully agonistic conformation. The EMBO journal 22, 4625-4633.

Swami, A., Reagan, M.R., Basto, P., Mishima, Y., Kamaly, N., Glavey, S., Zhang, S., Moschetta, M., Seevaratnam, D., Zhang, Y., et al. (2014). Engineered nanomedicine for myeloma and bone microenvironment targeting. Proceedings of the National Academy of Sciences of the United States of America 111, 10287-10292.

Swarnakar, S., Temel, R.E., Connelly, M.A., Azhar, S., and Williams, D.L. (1999). Scavenger receptor class $B$, type I, mediates selective uptake of low density lipoprotein cholesteryl ester. The Journal of biological chemistry 274, 29733-29739.

Tall, A.R., Yvan-Charvet, L., Terasaka, N., Pagler, T., and Wang, N. (2008). HDL, ABC transporters, and cholesterol efflux: implications for the treatment of atherosclerosis. Cell metabolism 7, 365-375.

Tangirala, R.K., Bischoff, E.D., Joseph, S.B., Wagner, B.L., Walczak, R., Laffitte, B.A., Daige, C.L., Thomas, D., Heyman, R.A., Mangelsdorf, D.J., et al. (2002). Identification of macrophage liver $X$ receptors as inhibitors of atherosclerosis. Proceedings of the National Academy of Sciences of the United States of America 99, 11896-11901.

Tarling, E.J. (2013). Expanding roles of ABCG1 and sterol transport. Current opinion in lipidology 24, 138-146.

Taylor, J.M., Allen, A.M., and Graham, A. (2014). Targeting mitochondrial $18 \mathrm{kDa}$ translocator protein (TSPO) regulates macrophage cholesterol efflux and lipid phenotype. Clinical science (London, England : 1979) 127, 603-613.

Traini, M., Quinn, C.M., Sandoval, C., Johansson, E., Schroder, K., Kockx, M., Meikle, P.J., Jessup, W., and Kritharides, L. (2014). Sphingomyelin phosphodiesterase acid-like 3A (SMPDL3A) is a novel nucleotide phosphodiesterase regulated by cholesterol in human macrophages. The Journal of biological chemistry 289, 32895-32913.

Tsang, S., Wu, S., Liu, J., and Wong, T.M. (2008). Testosterone protects rat hearts against ischaemic insults by enhancing the effects of alpha(1)-adrenoceptor stimulation. British journal of pharmacology 153, 693-709.

Tsankova, V., Visentin, M., Cantoni, L., Carelli, M., and Tacconi, M.T. (1996). Peripheral benzodiazepine receptor ligands in rat liver mitochondria: effect on 27-hydroxylation of cholesterol. European journal of pharmacology 299, 197-203.

Tsou, C.Y., Chen, C.Y., Zhao, J.F., Su, K.H., Lee, H.T., Lin, S.J., Shyue, S.K., Hsiao, S.H., and Lee, T.S. (2014). Activation of soluble guanylyl cyclase prevents foam cell formation and atherosclerosis. Acta physiologica (Oxford, England) 210, 799-810.

Ulven, S.M., Dalen, K.T., Gustafsson, J.A., and Nebb, H.I. (2005). LXR is crucial in lipid metabolism. Prostaglandins, leukotrienes, and essential fatty acids $73,59-63$.

van der Hoorn, J., Linden, D., Lindahl, U., Bekkers, M., Voskuilen, M., Nilsson, R., Oscarsson, J., Lindstedt, E., and Princen, H. (2011). Low dose of the liver $X$ receptor agonist, AZ876, reduces atherosclerosis in $\mathrm{APOE}^{*} 3$ Leiden mice without affecting liver or 
plasma triglyceride levels. British journal of pharmacology 162, 1553-1563.

van der Veen, J.N., Havinga, R., Bloks, V.W., Groen, A.K., and Kuipers, F. (2007). Cholesterol feeding strongly reduces hepatic VLDL-triglyceride production in mice lacking the liver $X$ receptor alpha. Journal of lipid research 48, 337-347.

van der Veen, J.N., van Dijk, T.H., Vrins, C.L., van Meer, H., Havinga, R., Bijsterveld, K., Tietge, U.J., Groen, A.K., and Kuipers, F. (2009). Activation of the liver $X$ receptor stimulates trans-intestinal excretion of plasma cholesterol. The Journal of biological chemistry 284, 19211-19219.

Vaughan, A.M., and Oram, J.F. (2005). ABCG1 redistributes cell cholesterol to domains removable by high density lipoprotein but not by lipid-depleted apolipoproteins. The Journal of biological chemistry 280, 30150-30157.

Wan, X., Huo, Y., Johns, M., Piper, E., Mason, J.C., Carling, D., Haskard, D.O., and Boyle, J.J. (2013). 5'-AMP-activated protein kinaseactivating transcription factor 1 cascade modulates human monocyte-derived macrophages to atheroprotective functions in response to heme or metformin. Arteriosclerosis, thrombosis, and vascular biology 33 , 2470-2480.

Wang, N., and Tall, A.R. (2003). Regulation and mechanisms of ATP-binding cassette transporter A1-mediated cellular cholesterol efflux. Arteriosclerosis, thrombosis, and vascular biology 23, 1178-1184.

Wang, Y., Li, C., Cheng, K., Zhang, R., Narsinh, K., Li, S., Li, X., Qin, X., Zhang, R., Li, C., et al. (2014). Activation of liver $X$ receptor improves viability of adipose-derived mesenchymal stem cells to attenuate myocardial ischemia injury through TLR4/NF-kappaB and Keap-1/Nrf-2 signaling pathways. Antioxidants and redox signaling 21, 2543-2557.

Westerterp, M., Bochem, A.E., Yvan-Charvet, L., Murphy, A.J., Wang, N., and Tall, A.R. (2014). ATP-binding cassette transporters, atherosclerosis, and inflammation. Circulation research 114, 157-170.

Wilund, K.R., Yu, L., Xu, F., Hobbs, H.H., and Cohen, J.C. (2004). High-level expression of ABCG5 and ABCG8 attenuates diet-induced hypercholesterolemia and atherosclerosis in Ldlr-/- mice. Journal of lipid research 45, 1429-1436.

Wu, C.H., Chen, C.C., Lai, C.Y., Hung, T.H., Lin, C.C., Chao, M., and Chen, S.F. (2016).
Treatment with T0901317, a synthetic liver X receptor agonist, reduces brain damage and attenuates neuroinflammation in experimental intracerebral hemorrhage. Journal of neuroinflammation 13, 62.

Wu, S., Yin, R., Ernest, R., Li, Y., Zhelyabovska, O., Luo, J., Yang, Y., and Yang, Q. (2009). Liver $X$ receptors are negative regulators of cardiac hypertrophy via suppressing NFkappaB signalling. Cardiovascular research 84, 119-126.

Yang, C., McDonald, J.G., Patel, A., Zhang, Y., Umetani, M., Xu, F., Westover, E.J., Covey, D.F., Mangelsdorf, D.J., Cohen, J.C., et al. (2006). Sterol intermediates from cholesterol biosynthetic pathway as liver $X$ receptor ligands. The Journal of biological chemistry 281, 27816-27826.

Yasuda, T., Grillot, D., Billheimer, J.T., Briand, F., Delerive, P., Huet, S., and Rader, D.J. (2010). Tissue-specific liver $X$ receptor activation promotes macrophage reverse cholesterol transport in vivo. Arteriosclerosis, thrombosis, and vascular biology 30, 781-786.

Yu, X.H., Qian, K., Jiang, N., Zheng, X.L., Cayabyab, F.S., and Tang, C.K. (2014). ABCG5/ABCG8 in cholesterol excretion and atherosclerosis. Clinica chimica acta; international journal of clinical chemistry 428 , 82-88.

Yuhanna, I.S., Zhu, Y., Cox, B.E., Hahner, L.D., Osborne-Lawrence, S., Lu, P., Marcel, Y.L., Anderson, R.G., Mendelsohn, M.E., Hobbs, H.H., et al. (2001). High-density lipoprotein binding to scavenger receptor-BI activates endothelial nitric oxide synthase. Nature medicine 7, 853-857.

Yvan-Charvet, L., Ranalletta, M., Wang, N., Han, S., Terasaka, N., Li, R., Welch, C., and Tall, A.R. (2007). Combined deficiency of ABCA1 and $A B C G 1$ promotes foam cell accumulation and accelerates atherosclerosis in mice. The Journal of clinical investigation 117 , 3900-3908.

Zelcer, N., Hong, C., Boyadjian, R., and Tontonoz, P. (2009). LXR regulates cholesterol uptake through Idol-dependent ubiquitination of the LDL receptor. Science (New York, NY) 325, 100-104.

Zelcer, N., and Tontonoz, P. (2006). Liver X receptors as integrators of metabolic and inflammatory signaling. The Journal of clinical investigation 116, 607-614.

Zhang, L., Reue, K., Fong, L.G., Young, S.G., and Tontonoz, P. (2012). Feedback regulation 
of cholesterol uptake by the LXR-IDOL-LDLR axis. Arteriosclerosis, thrombosis, and vascular biology 32, 2541-2546.

Zhang, X.Q., Even-Or, O., Xu, X., van Rosmalen, M., Lim, L., Gadde, S., Farokhzad, O.C., and Fisher, E.A. (2015). Nanoparticles containing a liver $X$ receptor agonist inhibit inflammation and atherosclerosis. Advanced healthcare materials 4, 228-236.
Zhao, C., and Dahlman-Wright, K. (2010). Liver $X$ receptor in cholesterol metabolism. The Journal of endocrinology 204, 233-240.

Zhao, J., Yan, H.M., Li, Y., Wang, J., Han, L., Wang, Z.H., Tang, M.X., Zhang, W., Zhang, Y., and Zhong, M. (2015). Pitavastatin calcium improves endothelial function and delays the progress of atherosclerosis in patients with hypercholesterolemia. Journal of Zhejiang University Science B 16, 380-387. 


\section{Microbiology / Molecular Biology}

Caister Academic Press is a leading academic publisher of advanced texts in microbiology, molecular biology and medical research. Full details of all our publications at caister.com

- Cyanobacteria: Omics and Manipulation Edited by: DA Los (2017) www.caister.com/cyano3

- Brain-eating Amoebae: Biology and Pathogenesis of Naegleria fowleri

Author: R Siddiqui, IKM Ali, JR Cope, et al. (2016)

"explains the current knowledge and research" (ProtoView) www.caister.com/naegleria

- Foot and Mouth Disease Virus: Current Research and Emerging Trends

Edited by: F Sobrino, E Domingo (2017)

www.caister.com/fmdv

- Staphylococcus: Genetics and Physiology

Edited by: GA Somerville (2016)

www.caister.com/staph2

- Chloroplasts: Current Research and Future Trends Edited by: H Kirchhoff (2016)

www.caister.com/chloroplasts

- Microbial Biodegradation: From Omics to Function and Application

Edited by: J Długoński (2016)

www.caister.com/biodegradation

- Influenza: Current Research

Edited by: Q Wang, YJ Tao (2016)

www.caister.com/flu3

- MALDI-TOF Mass Spectrometry in Microbiology Edited by: M Kostrzewa, S Schubert (2016)

www.caister.com/malditof

- Aspergillus and Penicillium in the Post-genomic Era Edited by: RP Vries, IB Gelber, MR Andersen (2016)

"new and well-presented book" (IMA Fungus)

www.caister.com/aspergillus2

- The Bacteriocins: Current Knowledge and Future

Prospects

Edited by: RL Dorit, SM Roy, MA Riley (2016)

www.caister.com/bacteriocins

- Omics in Plant Disease Resistance

Edited by: V Bhadauria (2016)

"essential reading ... highly recommended" (Biotechnol. Agron.

Soc. Environ.)

www.caister.com/opdr

- Acidophiles: Life in Extremely Acidic Environments

Edited by: R Quatrini, DB Johnson (2016)

"Contributors from a wide range of biological and environmental sciences" (ProtoView)

www.caister.com/acidophiles
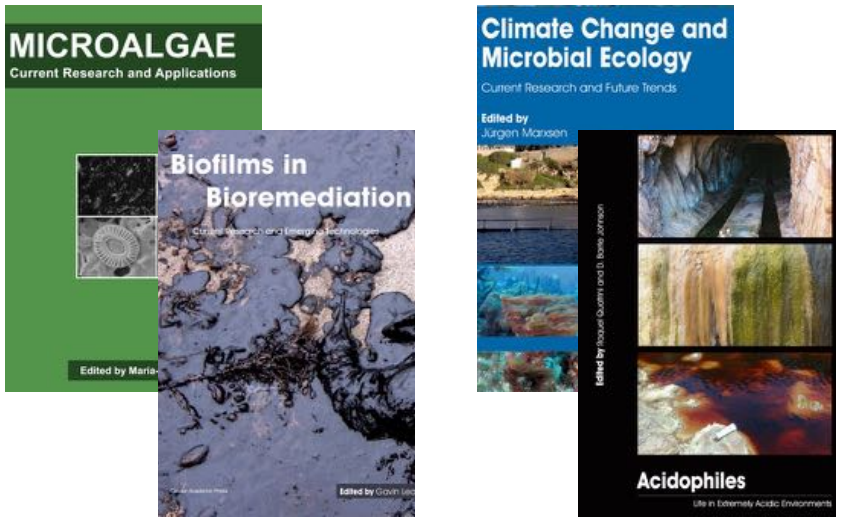
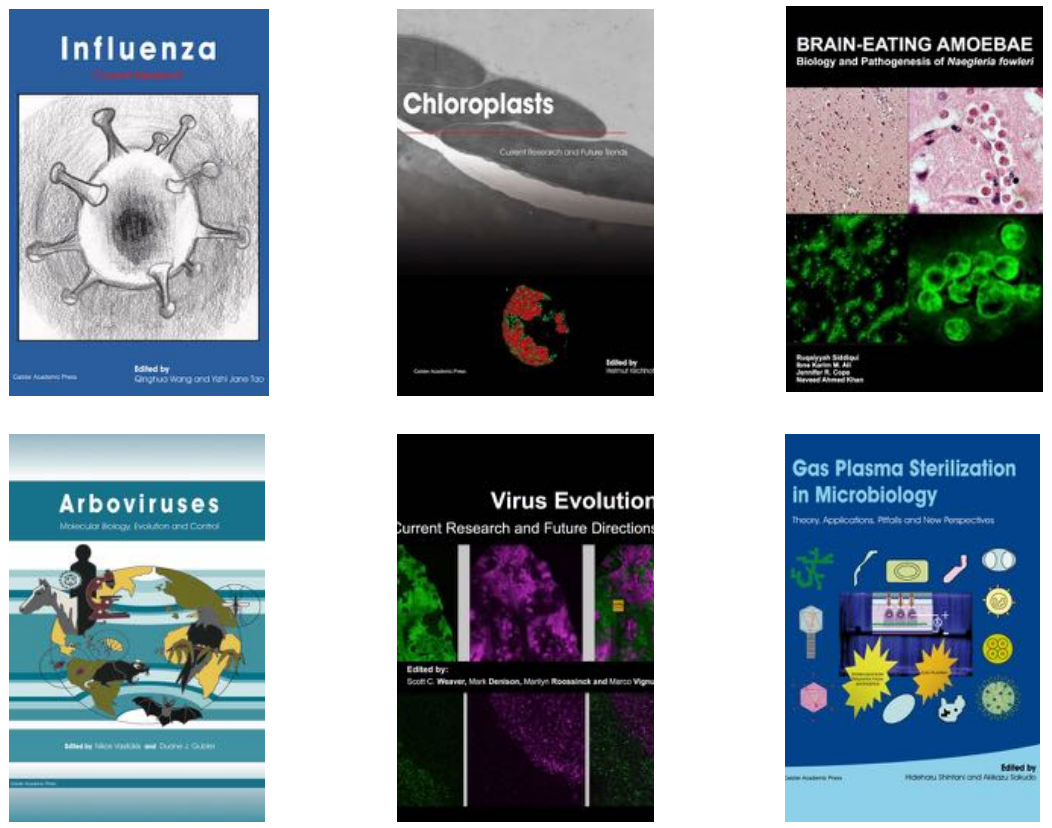

- Climate Change and Microbial Ecology: Current Research and Future Trends

Edited by: J Marxsen (2016)

"impressive" (ASM: Small Things Considered); "written at a high scientific level" (BioSpektrum)

www.caister.com/climate

- Biofilms in Bioremediation: Current Research and Emerging Technologies

Edited by: G Lear (2016)

"describes explicitly the role of biofilms in bioremediation" (Biospektrum); indispensable ... recommended (Biotechnol. Agron. Soc. Environ.) www.caister.com/biorem

- Microalgae: Current Research and Applications

Edited by: MN Tsaloglou (2016)

www.caister.com/microalgae

- Gas Plasma Sterilization in Microbiology: Theory, Applications, Pitfalls and New Perspectives

Edited by: H Shintani, A Sakudo (2016)

"a nice state of the art compilation" (Doodys)

www.caister.com/gasplasma

- Virus Evolution: Current Research and Future Directions Edited by: SC Weaver, M Denison, M Roossinck, et al. (2016) "highly informative ... a pleasure to read" (Microbiol. Today) www.caister.com/virusevol

- Arboviruses: Molecular Biology, Evolution and Control Edited by: N Vasilakis, DJ Gubler (2016)

"a thorough and compelling review ... an outstanding book ... highly recommended" (Am. J. Trop. Med. Hyg.) www.caister.com/arbo

- Shigella: Molecular and Cellular Biology

Edited by: WD Picking, WL Picking (2016)

www.caister.com/shigella

- Aquatic Biofilms: Ecology, Water Quality and Wastewater Treatment

Edited by: AM Romaní, H Guasch, MD Balaguer (2016)

"essential reference book" (Biotechnol. Agron. Soc. Environ.)

www.caister.com/aquaticbiofilms

- Alphaviruses: Current Biology

Edited by: S Mahalingam, L Herrero, B Herring (2016)

"up-to-date review of the field" (Aus. Vet. J.)

www.caister.com/alpha 